\title{
التطبيق الأصولي على أحاديث الأحكام \\ (بعض أحاديث الطهارة من عمدة الأحكام أنموذجًا)
}

\author{
د. مشهور بن حاتم بن حامد الحارثي

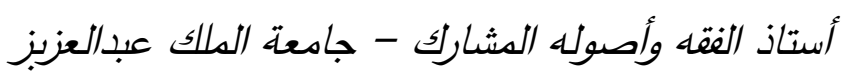 \\ كلية الآداب والعلوم الإنسانية \\ قسم الثريعة والدراسات الإسلامية
}

مستخلص. فهذا بحث بعنوان: "التطبيق الأصولي على أحاديث الأحكام - بعض أحاديث الطهارة من عمدة الأحكام

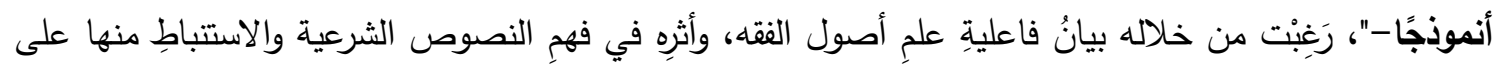

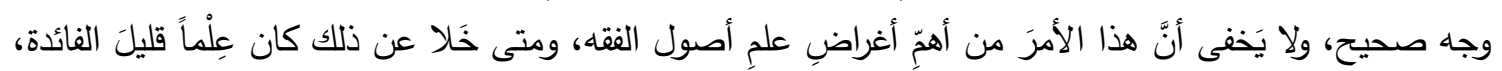
ضعيف الأثر. وقد قسَّت هذا البحث إلى ثلاثة مباحث وخاتمة، المبحث الأول في تعريف التطبيق الأصولي لغة واصطلاحًا،

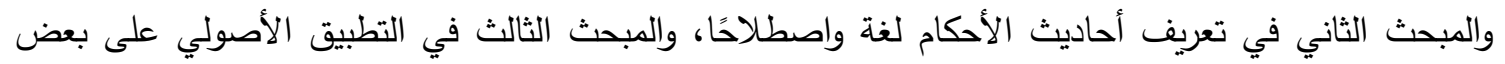

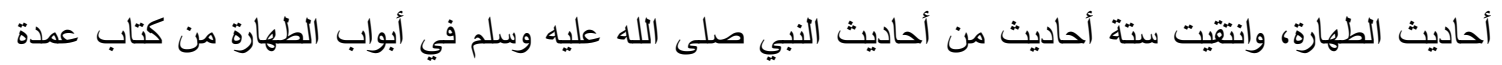
الأحكام للإمام المقدي رحمه الله تعالى لإعمال القواعد الأصولية والفقهية عليها.

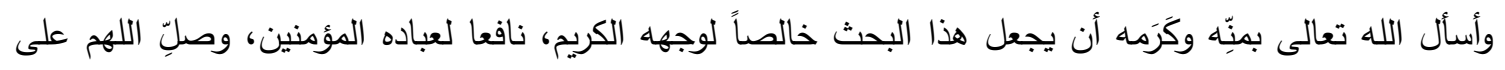
نبينا محمد وعلى آله وصحبه وسلِّم.

الفقه، وأثرِه في فهم النصوص الثرعية والاستتباطِ المقدمة

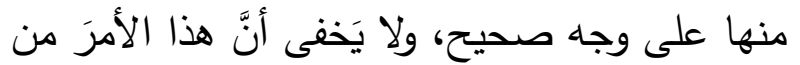

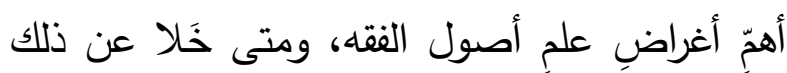

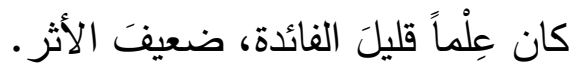
وقد رأيتُ أن أنتقيَ بعضَ أحاديثِ الأحكام من كلام

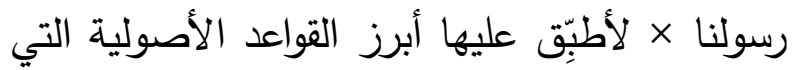

الحمد لله رب العالمين، والصلاة والسلام على الهادي الأمين، وعلى آله وصحبه أجمعين، وبعد.. فهذا بحث بعنوان: "التطبيق الأصولي على أحاديث وعين وليثل الأحكام - بعض أحاديث الطهارة من عمدة الأحكام

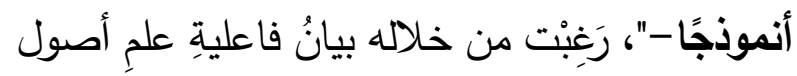


ابن الوزير اليماني رحمه الله (ت:بV آهـ) بقوله:

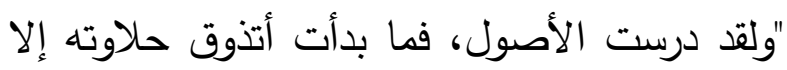
منذ أن شرعت في دراسة علم الحديث وشروحه الفقهية، مثل: الروض النضير، وسبل السلام، وفتح الباري، ومثل: العمدة التي فاقت أخواتها من هذه لرونه الناحية التطبيقية للأصول خاصة، فمؤلفها ذلك الثيخ العلامة المحقق الأصولي الثهير بابن دقيق العيد

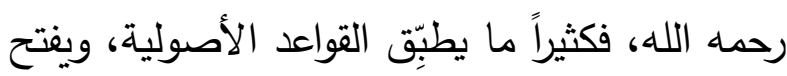

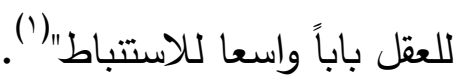

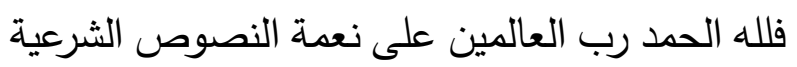
من كتاب وسنة، وعلى ما بذله علماؤنا رحمه الله الأجلاء من طرق هادية للوصول إلى الحكم الثرعي بشكل صحيح. منهجي في البحث:

توثيق المعلومات بالعزو لمصادئ لمترها الأصلية المتقدمة ثم المتأخرة. عزو الآيات الواردة في البحث بذكر اسم السورة ورقم الآية بعد الآية مباشرة في صلب البحث. تخريج الأحاديث من مصادرها الأصلية، والاكتفاء الأهبه

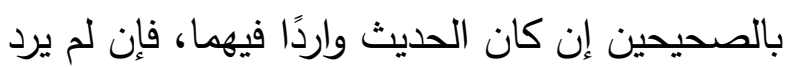
فيهما خرَّجته من كتب السنة الأخرى، مع ذكر درجته وحكم المحثين عليه رحمهم الله تعالى.
قرَّرها علماء الأصول رحمهم الله تعالى في كتبهم، سواءً منها ما يتعلَّق بالدَّلاتلات اللفظية أو العِلِ والمعاني الشرعية أو غير ذلك.

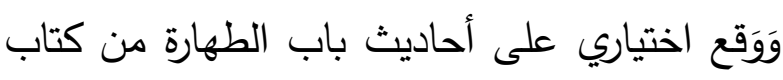
عمدة الأحكام للإمام عبدالغني المقدسي رحمه الله بله باله

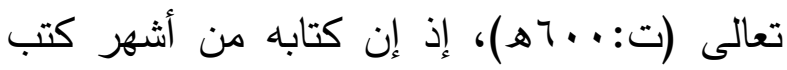
أحاديث الأحكام وأصدِّها، فقد اعتمَد ذكرَ الأحاديث المخرَّجة في صحيحي البخاري (ت:به بهـ ) ومسلم (ت: آTYه) رحمهما الله تعالى، فعَمِلت على تطبيق أهمّ قواعد علم الأصول عليها، واستتباط الأحكام

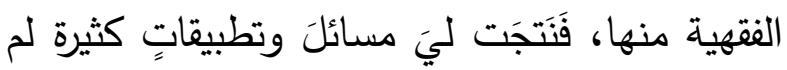

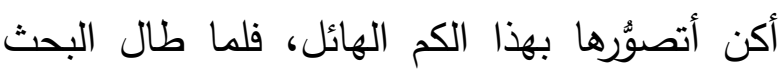

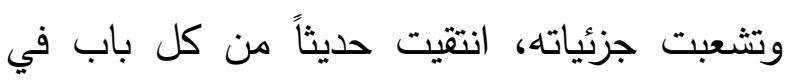
الطهارة، وطبَّتت أهمَّ القواعد الأصولية عليه، وتتبََّّت

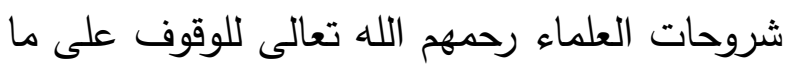
يؤِِّّ من أقوالهم وإثاراتهم صحة التطبيق الأصولي من عدمه. - من. ولا أُخفِي سرًاً أني وجدت في نفسي استمتاعاً عجيباً

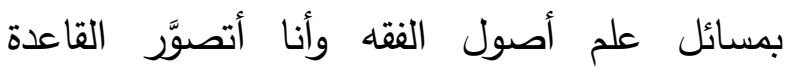
الأصولية كما هي في كتب الأصوليين رحمه الله،

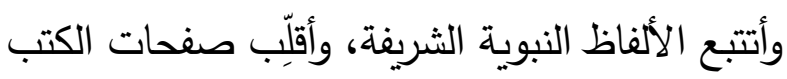
والثروح للعثور على نصوص شاهدة من أقوال

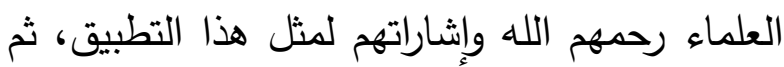
وقفت على نص بديع يوافق ما وَقَّع في نفسي، يحكيه 
ا. الـ مراعاة الترتيب الزمني عند ذكر المصادر في الآتي:

المبحث الأول: تعريف التطبيق الأصولي لغة واصطلاحًا، وفيه ثلاثة مطالب:

المطلب الأول: تعريف (التطبيق) لغة واصطلهاً مطاّل المطلب الثاني: تعريف (الأصولي) لغة واصطلاحًا

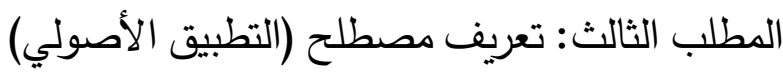

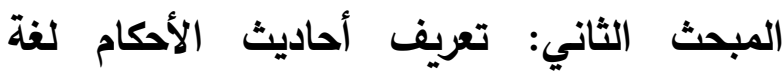
واصطلاحًا، وفيه ثلاثة مطالب:

المطلب الأول: تعريف (أحاديث) لغة واصطهل مطلانًا المطلب الثاني: تعريف (الأحكام) لغة واصطلاحًا المطلب الثالث: تعريف مصطلح (أحاديث الأحكام) المبحث الثالث: التطبيق الأصولي على بعض أحاديث الطهارة، وفيه ستة مطالب: المطلب الأول: التطبيق الأصولي على حديث: "لاديه مطئ

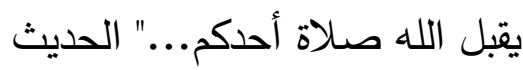
المطلب الثاني: التطبيق الأصولي على حديث: "إذا شرب الكلب من إناء أحدكم..." الحديث المطلب الثالث: التطبيق الأصولي على حديث: "لتولاه احلى

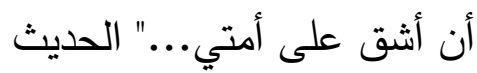
المطلب الرابع: التطبيق الأصولي على حلى حديث: "يغسل ذكره ويتوضأ" المطلب الخامس: التطبيق الأصولي على حديث:

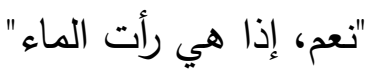
المطلب السادس: التطبيق الأصولي على حديث: "لا، إن ذلك عرق.." الحديث وأسأل الله تعالى بمنِّه وكَرَمها أن يجعل هذا البحث
الحاشية. r. لم أترجم للأعلام الواردة أسماؤهم في البحث خشية الإطالة، واكتثيت بذكر تاريخ الوفاة بعد اسم العَلَم في صلب البحث. منهجي في التطبيق الأصولي: 1. أذكر الحديث كما أورده صاحب لاصني عمدة الأحكام رحمه الله تعالى معزوًا للصحيحين. r. أقوم بتحليل ألفاظ الحديث تحليلاً أصولياً، مبيّناً ما يشتمل عليه من مسائل الأمر والنهي والعام والخاص والمطلق والمقيد والمجمل والمبين وغيرها من من منئن

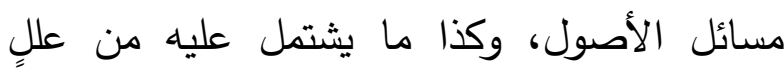
ومعاني شرعية. r. أذكر ما وقفت عليه من كلام العلماء رحمه الله تعالى من المتقِِّّمين والمعاصرين حول استشهادهم بالقاعدة الأصولية عند شرحهم للحديث، لا سيما شروحات عمدة الأحكام القديمة والمعاصرة، مراعياً في ذلك الترتيب الزمني لنقولاتهم.

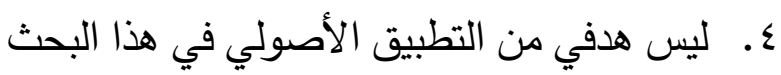

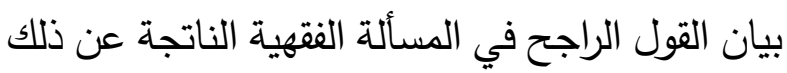
التطبيق، وإنما الهدف هو: بيان أثر علم أصول الفقه

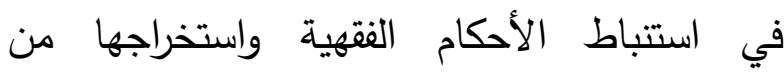
النصوص حسبما ذكره علماء أصول الفقه رحمه الله. خطة البحث: قسمت هذا البحث إلى ثلاثة مباحث وخاتمة، وهي 
خالصاً لوجهه الكريم، هادياً ليَ الصراط المستقيم، بالمطر. r. بإصـابة الثيء : وأصله من إصلابة المِفْصَل، يقال:

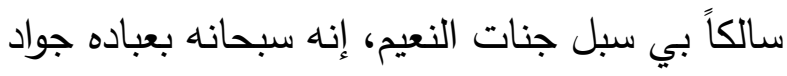

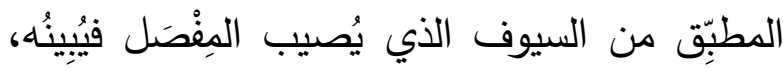

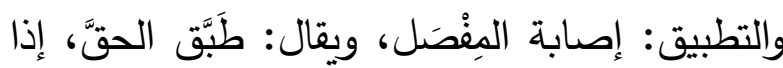

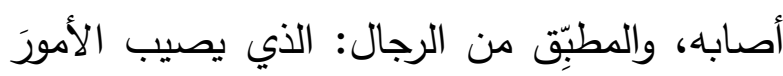

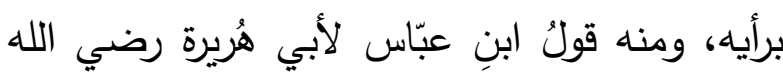

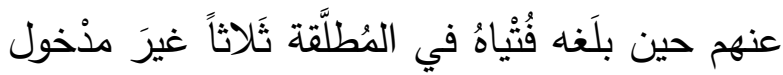

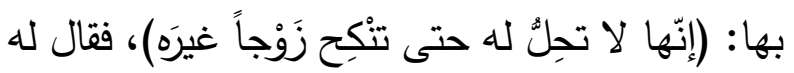

•

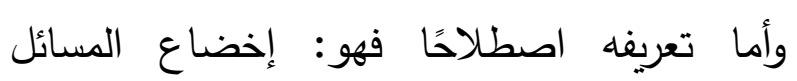
والقضايا لقاعدة علمية أو قانونية أو نحوها(؛). المطلب الثاني: تعريف (الأصولي) لغة واصطلاحًا

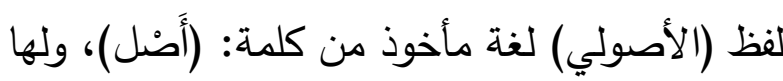
عدة معان في اللغة، منها (م) ا. أسفل الثي وأساسه: يقال: (أصل الثجرة) أي:

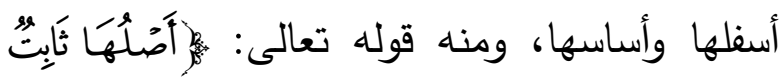

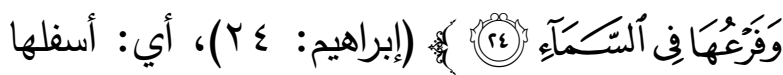

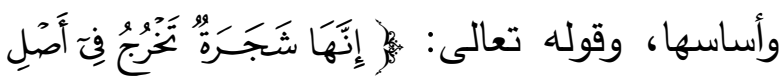

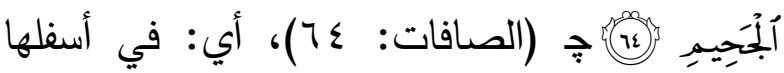
وقعْرها.

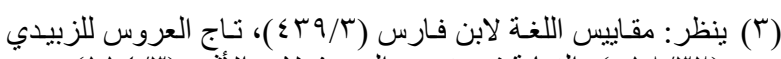

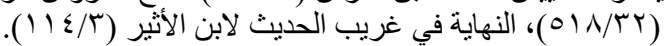

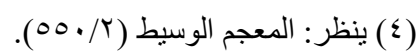

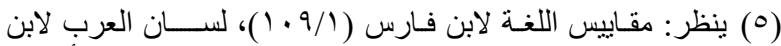

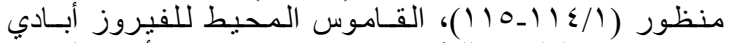

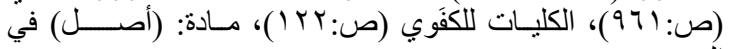

رحيم..وصلِّ اللهم على نبينا محمد وعلى آله وصحبه

وسلّمِ.

المبحث الأول: تعريف (التطبيق الأصولي) لغة واصطلاحًا، وفيه ثلاثة مطالب: المطلب الأول: تعريف (التطبيق) لغة واصطلاحًا المطلب الثاني: تعريف (الأصولي) لغة واصطلاحًا المطلب الثالث: تعريف مصطلح (التطبيق الأصولي) المطلب الأول: تعريف (التطبيق) لغة واصطلاحًا لفظ (التطبيق) لغة مأخوذ من كلمة (طَبقَ)، وجَمْعُها: أَطْباق، وله في اللغة عدة معان، منها (')

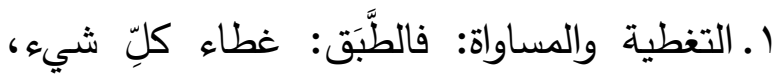
وتطابق الثيئان: إذا تساويا، ويقال: طابقت بين الثيائين، إذا جعلتهما على حذِِ واحدٍ وألَزَقَتَهما، ومنه

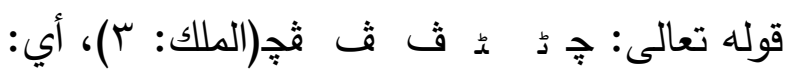
بعضها فوق بعض.

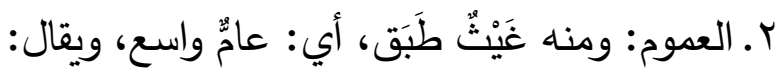

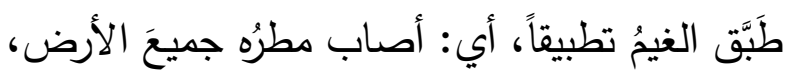

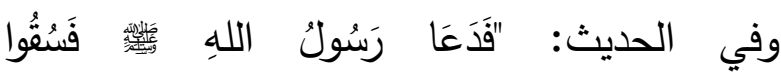

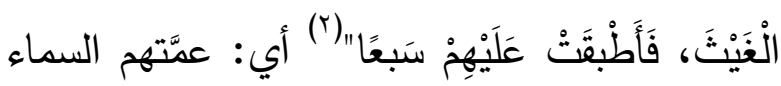

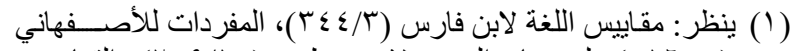

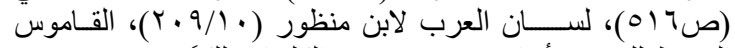

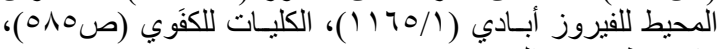

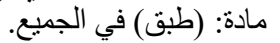

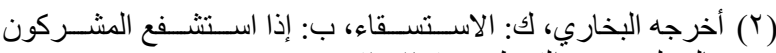
بالمسلمين عند القحط، ح ( r • ( ). 
الفقه وما يتوصل به إلى الأدلة على سبيل

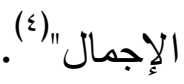

ع.تعريف الغزالي رحمه الله (ت:0.0 0ه): "عبارة عن أدلة هذه الأحكام، وعن معرفة وجوه دلالتها على رهلى

الأحكام من حيث الجملة لا من حيث التفصيل" (o.).

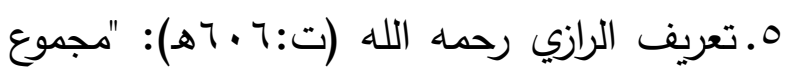
طرق الفقه على سبيل الإجمال، وكيفية الاستفادة

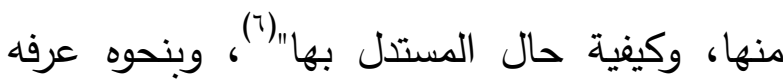

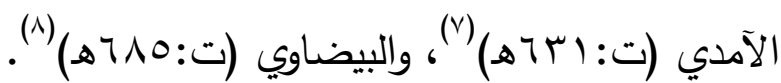

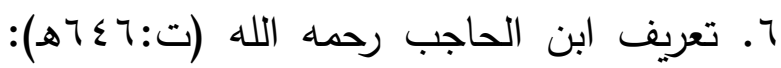
"العلم بالقواعد التي يتوصل بها إلى استتباط الأحكام

الثرعية الفرعية عن أدلتها التفصيلية"(9).

$$
\text { التعريف المختار : }
$$

جميع التعريفات السابقة متقاربة، ولا تَسْلَم من نقد واعتراض، ولعلَّ من أشهرها تعريف الرازي رحمه الله تعالى وهو:

"مجموع طرق الفقه على سبيل الإجمال، وكيفية

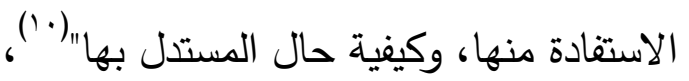
وبيان محترزات التعريف كالآتي:

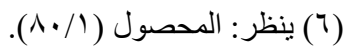

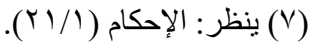

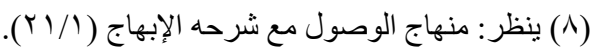

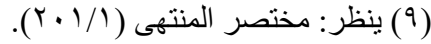

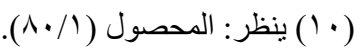

r. الثبوت: يقال: استأصَلَت الشجرةُ، أي: ثَبَت أصلُها، ورجلٌ أصيلّ، أي: ثابتُ الرأي عاقلُ.

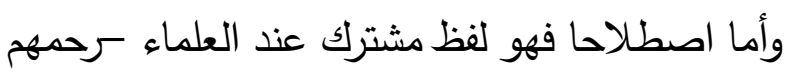
الله- بين عدَّة معان، منها (') ا ـ الدليل، ومنه قولهم: الأصل في تحريم الربا قوله

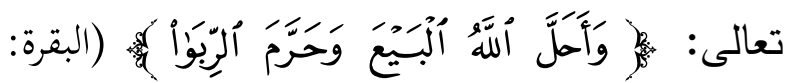
.$($ rVo

r. الراجح، ومنه قولهم: "الأصل في الكلام الحقيقة". r. القاعدة المستمرة في الشرع، ومنه قولهم: "أكل الميتة على خلاف الأصل". ـ. المقيس عليه، وهو ما يقابل الفرع في باب القياس. ومراد العلماء كرحمه الله- ب(الأصولي) هنا نسبة إلى الأصول، وهي: "علم أصول الفقه"، وقد عرَّفوا هذا العلم بتعريفات كثيرة في الاصطلاح، منها:

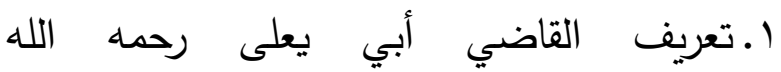

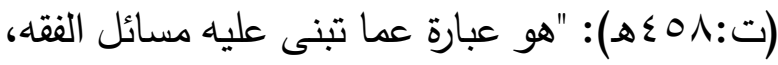

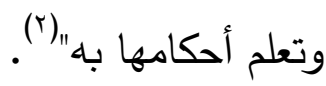

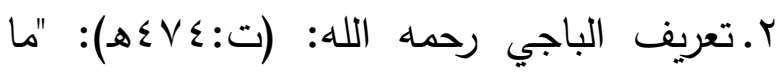

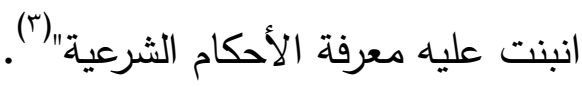

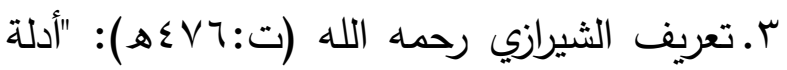

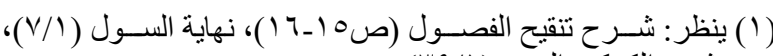

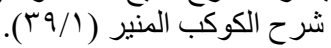

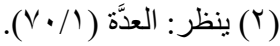

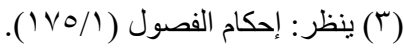

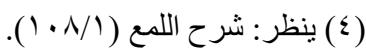

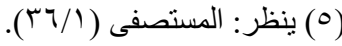


(إعمال القاعدة الأصولية في النص لفهم المعنى أو (ستنباط الحكم) وبيان محترزات التعريف كالاتي: قوله: (إعمال) المراد به: الإشغال والتفعيل، وخرج به: الإهمال وهو: الترك والتقصير • وقوله: (القاعدة الأصولية) أي: قواعد علم أصول الفقه، وخرج به: القاعدة النحوية والصرفية وغيرها مما لا علاقة له بعلم أصول الفقه. وقوله: (في النص) يشمل النص الشرعي كتابًا وسنة، ويشمل نصوص المكلفين وعباراتهم التي يترتب عليها أحكام شرعية كعبارات الأوقاف والوصايا وغيرها.

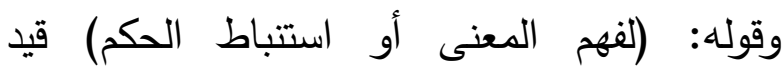
توضيحي؛ لبيان ثمرة إعمال القاعدة الأصولية في النص، فإما أن يكون لفهم معنى النص وصحة إنس تصوُره، أو لاستتباط الحكم منه. المبحث الثاني: تعريف أحاديث الأحكام لغة لاسبام واصطلاحاً، وفيه ثلاثة مطالب:

المطلب الأول: تعريف (أحاديث) لغة واصطلاحًا المطلب الثاني: تعريف (الأحكام) لغة واصطلاحًا المطلب الثالث: تعريف مصطلح (أحاديث الأحكام) المطلب الأول: تعريف (أحاديث) لغة واصطلاحًا كلمة (الأحاديث) مُفْرَدها (حديث)، ويطلق في اللغة

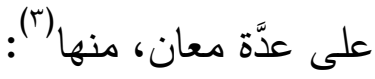

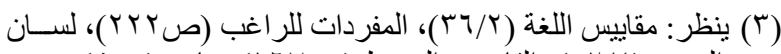

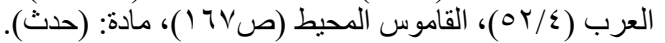

وقوله: (مجموع طرق الفقه على سبيل الإجمال): المراد بها الأدلة الثرعية الكلية للفقه التي لا تدل على سلى الإلى

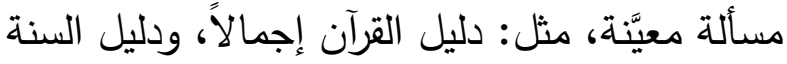

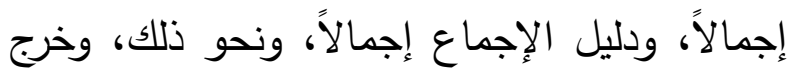
بهذا القيد: أدلة الفقه التقصيلية المختصة بمسائل معينة، فلا تذكر في أصول الفقه إلا على سبيل

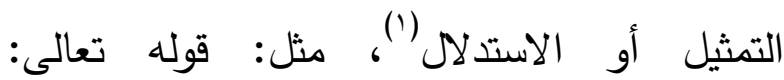

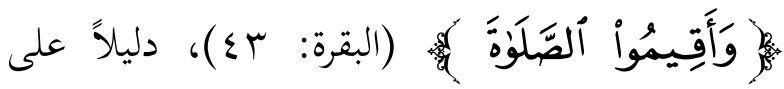
وجوب صلاة الفريضة، وقوله صلى الله عليه وسلم:

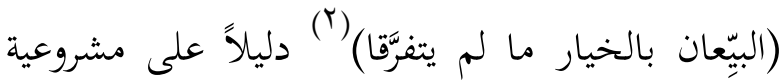

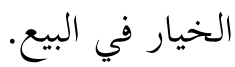
وقوله: (وكيفية الاستفادة منها): أي: بيان صفة استنباط

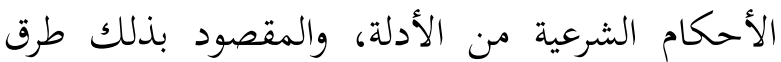
الاستباط، مثل: قواعد الأمر والنهي، والعام والخاص، والمنطوق والمفهوم، وغيرها. وقوله: (وكيفية حال المستدل بها): والمراد: بيان صفة المجتهد الذي يستدل بالأدلة، ويستنبط الأحكام

$$
\text { الشرعية منها. }
$$

المطلب الثالث: تعريف مصطلح (التطبيق الأصولي)

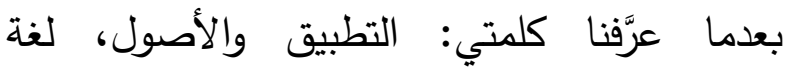
واصطلاحًا، يمكن أن نُعرَّف مصطلح (التطبيق

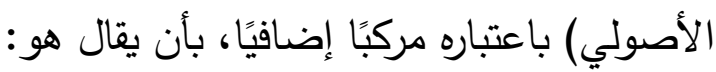

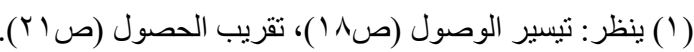

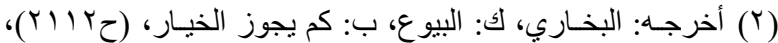

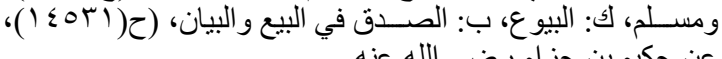


ومثال صفته ×: "كان رسول الله × أحسن الناس

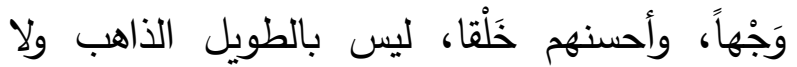

$$
\text { بالقصير |" (0). }
$$

المطلب الثاني: تعريف (الأحكام) لغة واصطلاحًا

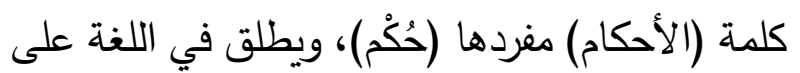

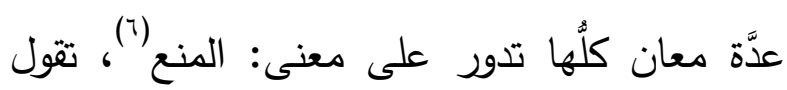

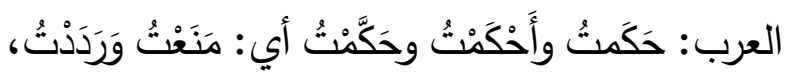
وسمِّي القاضي بين الناس حاكِماً؛ لأنه يمنع الظالم

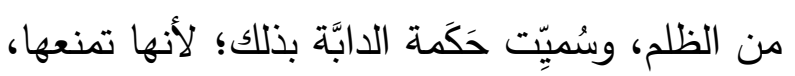

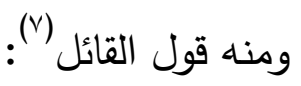

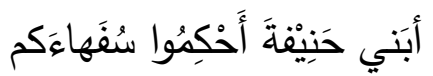
إني أخاف عليكمُ أنْ أَغْضَبا

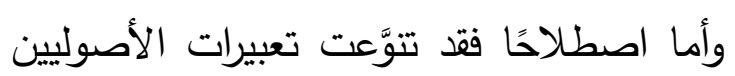
رحمهم الله في تعريفهم له اصطلاحاً بتعريفات

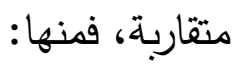
ا.تعريف الغزالي رحمه الله (ت:0.0هـ) بقوله:

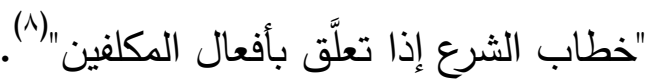
r.تعريف الرازي رحمه الله (ت:T • آهـ) بقوله:

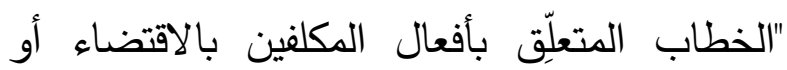

$$
\begin{aligned}
& \text { ( ) أخرجه: مسلم، كَ: المساجد ومو اضع الصـلاة، ب: تحريم الكلام في } \\
& \text { الصلاة..، ح: (ك) (orv). }
\end{aligned}
$$

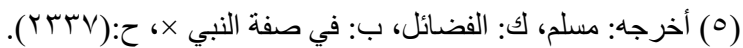

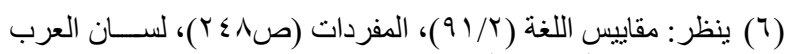

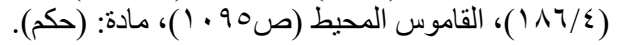

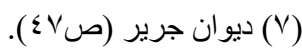

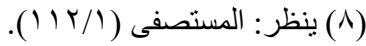

1. الجديد من الأشياء: وهو نقيض القديم، والحدوث: كون الثيء لم يكن، يقال: حَدَث أمرٌ بعد

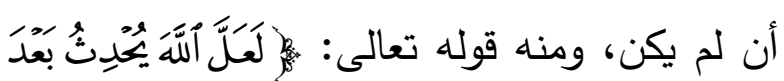

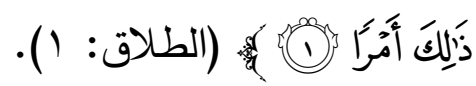

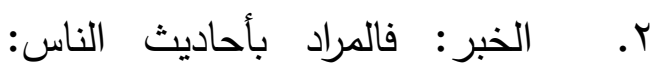

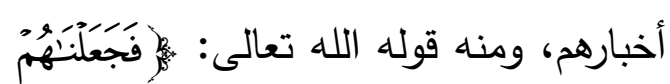
أَحَادِيثَ به: (سبأ: 9 (1)، أي: أخباراً لمن يأتي

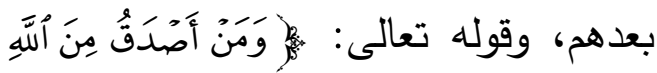

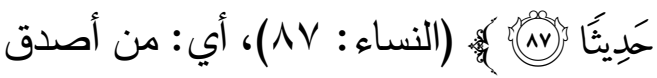
منه خبراً.

وأما معنى الحديث اصطلاحاً فهو: ما أضيف إلى النبي × من قول أو فعل أو تقرير أو صفة '(') فمثال قوله ×: حديث: "ليس فيما دون خمسة أوسق صدقة" (r) ومثال فعله ×: حديث: أن رسول الله × "صلَّى في جوف الكعبة بين العمودين اليمانيين"("). ومثال تقريره ×: حديث الجارية التي سألها رسول الله ×: أين الله؟ قالت: في السماء، فأقرَّها على ذلك (ء). 
المبحث الثالث: التطبيق الأصولي على بعض

أحاديث الطهارة، وفيه ستة مطالب:

المطلب الأول: التطبيق الأصولي على حديث: "لأل

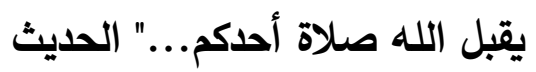
المطلب الثاني: التطبيق الأصولي على حديث: "إذا شرب الكلب من إناء أحدكم..." الحديث المطلب الثالث: التطبيق الأصولي على حديث: "لولاء أن أثثق على أمتي..." الحديث: المطلب الرابع: التطبيق الأصولي على حديث:

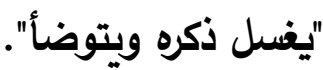
المطلب الخامس: التطبيق الأصولي على حديث: "تعم، إذا هي رأت الماء". المطلب السادس: التطبيق الأصولي على حديث: "لا، إن ذلك عرق.." الحديث المطلب الأول: التطبيق الأصولي على حديث: "لا" يقبل الله صلاة أحدكم..." الحديث متن الحديث: - متر

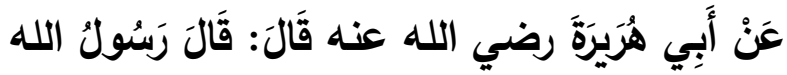

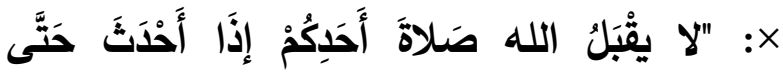

يتوَضَّاًَ"(؛) التطبيق الأصولي:

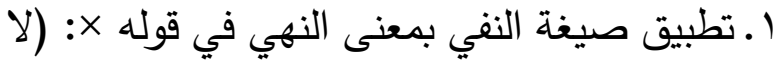
يقبلُ الله)، وهذا الأسلوب أبلغ من مجرد النهي والزجر هئه

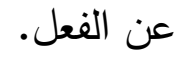

التخيير"(') r.تعريف الآمدي رحمه الله (ت:اسآه)بقوله: "خطاب الثارع المفيد فائدة شرعية"(؟). ع.تعريف ابن الحاجب رحمه الله (ت:7؟7ه) بقوله: "خطاب الله تعالى المتعلّق بأفعال المكلفين

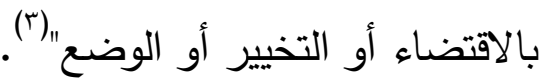
المطلب الثالث: تعريف مصطلح (أحاديث الأحكام) لم يَخََْ هذا المصطلح (باعتباره مركَّبًا إضافيَّا)

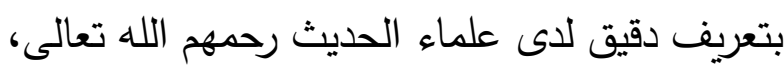
ويمكن تعريفه بالآتي: (الأحاديث النبوية المتعلِّة بالأحكام الفقهية قَصْدًا). وبيان محترزات هذا التعريف كما يلي: قوله (الأحاديث النبوية): المقصود به قول النبي × أو فعله أو تقريره، وخرج باديه الآيات القرآنية،

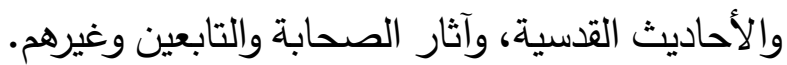

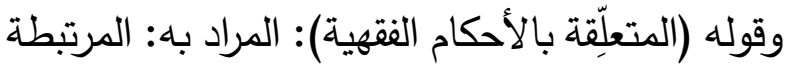

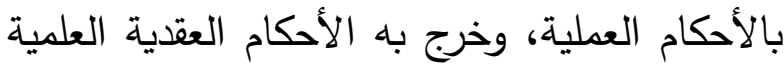

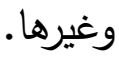
وقوله (قَصْدًا): خرج بهاء الأحاديث التي تضمَّنت أحكاماً فقهية على سبيل التبع والاستتباط من العلماء رحمهم الله تعالى، مع كونها لم تُسَق لبيان الأحكام الفقهية على وجه الخصوص، مثل بعض الأحكام الفقهية المستتبطة من القصص والأخبار النبوية. 


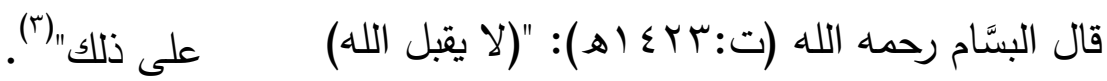
وقال الفاكهاني رحمه الله (ت:؟عبهـ): "وتحقيقه أن

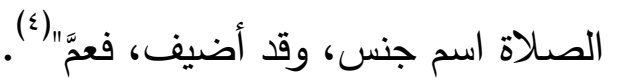

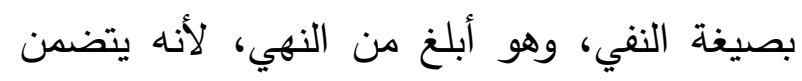
النهي وزيادة نفي حقيقة الشيء" (')

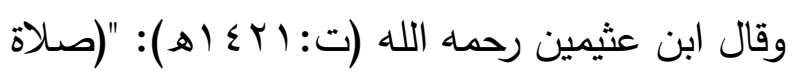

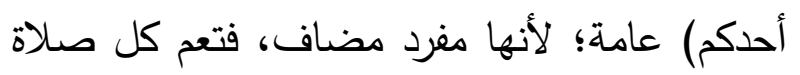

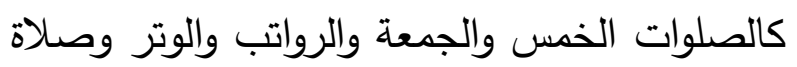
الجنازة والنفل المطلق كل هذا داخل في اللفظ، لأنه يشمل العموم"(ن). 7.تطبيق صيغة العدوم في قوله ×: (أحدكم)،

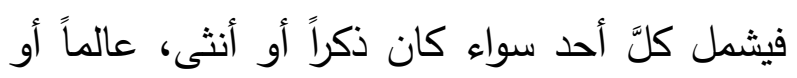

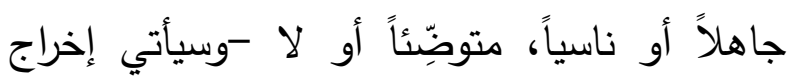
المتوضئ من العموم في آخر الحديث-؛ وذلك لدلالة المفرد المضاف على العموم.

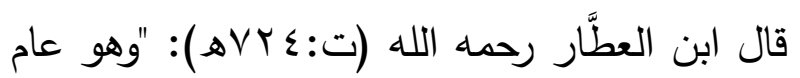
في عدم القبول من جميع المحدثين في جميع أنواع

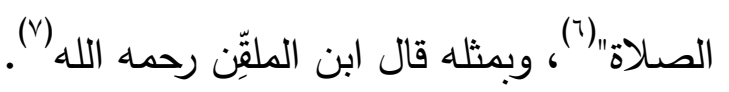

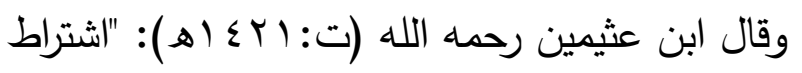
الطهارة لكل من أراد الصلاة وكان محدِثاً؛ لعموم

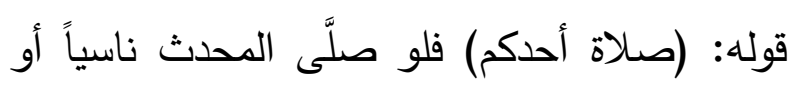
جاهلاً فصلاته مردودة؛ لأن الحديث لم يقِّد، وعليه الإعادة، ويرتفع عنه الإثم.."(^).

$$
\begin{aligned}
& \text { (0) ينظر : شرح عمدة الأحكام (YV/I) : (1) }
\end{aligned}
$$

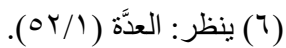

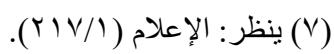

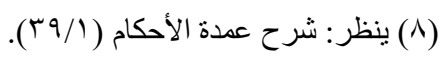

Y.تطبيق قاعدة: "النهي يقتضي الفساد": فإنه لما نهى عن الصلاة حال الحدث اقتضى ذلك فساد صلاة من صلَّى وهو محدث. r. تطبيق قاعدة: "النهي عن الثيء أمر بضدِّده": فإنه

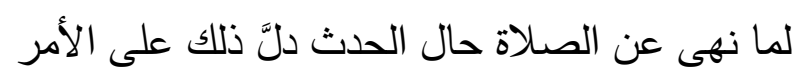
بالطهارة للصلاة. ع.تطبيق صيغة العموم في قوله ×: (لا يقبل)، فيشمل نفي كل قبول من الله تعالى؛ لدلالة الفعل الواقع في سياق النفي على العموم.

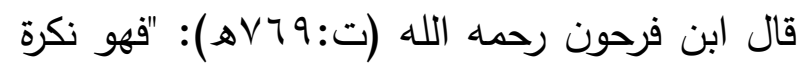

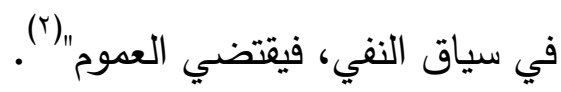
ه. تطبيق صيغة العموم في قوله × فيشمل كلَّ صلاة سواء كانت صلاة فريضة أو نافلة

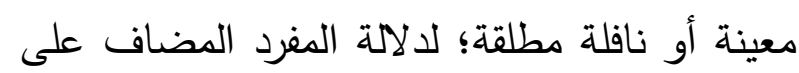
العموم. قال ابن العطَّار رحمه الله (ت: \&YYهـ) : "وحكي عن الثعبي ومحمد بن جرير الطبري من قولهما جواز صلاة الجنازة بغير طهارة، وهو مذهب بط باطل،

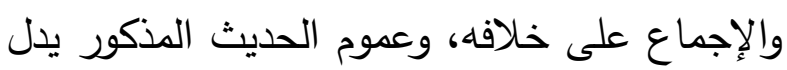

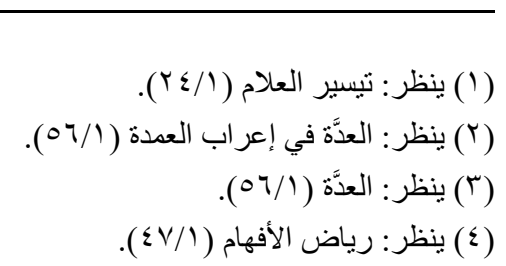


قبلها فيقتضي ذلك قبول الصلاة بعد الوضوء مطلقا وتتخل تحته الصلاة الثانية قبل الوضوء لها ثانيا"(").

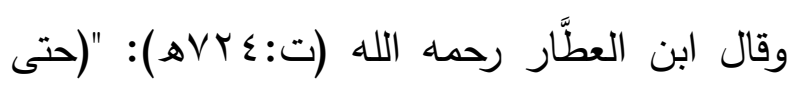

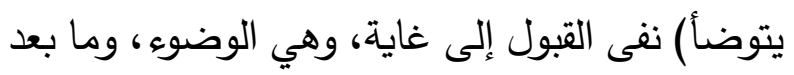

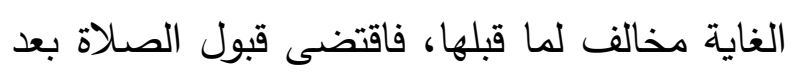
الوضوء مطلقاً، ودخل تحته الصلاة الثانية قبل الوضوء لها ثانياً، وهذا مجمع عليه في الوضوء" (؛ُ).

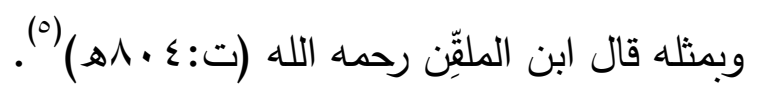

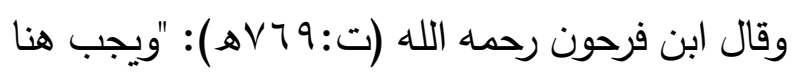
تقدير "حتى" ب"إلىى" التي للغاية"(־).

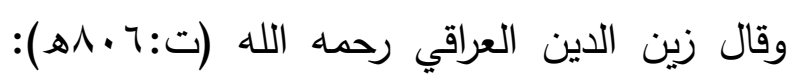

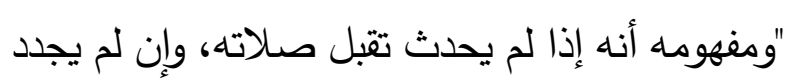

$$
\text { وضوء آ" (v) }
$$

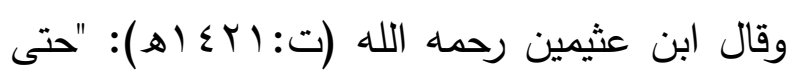
هنا غائية المعنى، أي: إلى أن يتوضأ" (^). • ل . تطبيق مفهوم الشرط في الحديث في قوله ×: "لا يقبل الله صلاة أحدكم إذا أحدث.."، ومفهومه: أن الله تعالى يقبل الصلاة إذا لم يحدث صاحبها ولا يشترط أن يتوضأ لها وضوءاً - خاصاً.

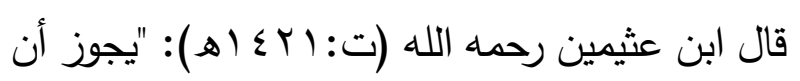

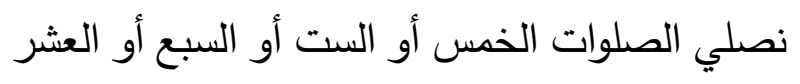
بوضوء واحد،. .لقوله: "إذا أحدث" ولقد صلى النبي ل

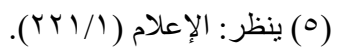

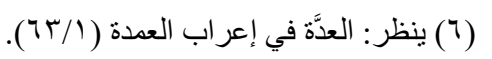

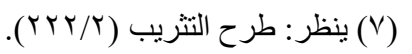

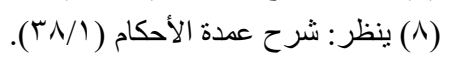

V.تطبيق صيغة العموم في قوله ×: (إذا أحدث)،

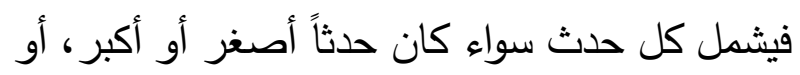

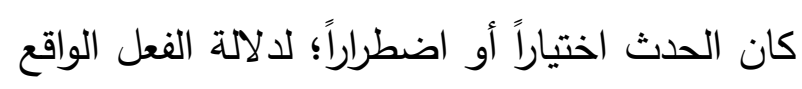
في سياق الثرط على العموم.

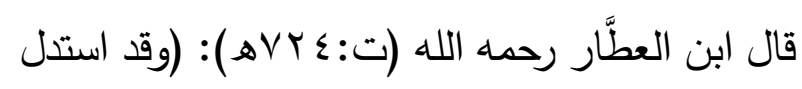

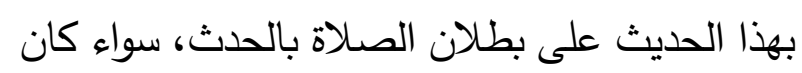

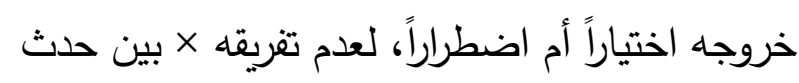
وحدث في حالة دون حالة، وقد حكي عن مالك

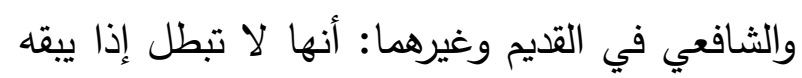
الحدث، بل يتوضأ ويني على صلاته، وإطلاق الحديث يرده"|(') وبمثله قال ابن الملقِّن رحمه الله وبنه

$$
\text { . ( ) }
$$

^. تخصيص متصل (بالغاية) في قوله ×: (حتى يتوضأ)، فأخرج المصلي المتوضئ من عموم نفي القبول، فتقبل صلاته. 9. تطبيق مفهوم الغاية في قوله ×: (حتى يتوضأ) فإن مفهومه أنه تقبل صلاته إذا توضأ، ولو تعدَّدت الصلوات. قال ابن دقيق العيد رحمه الله (ت:Y • Vهـ): "الوجه

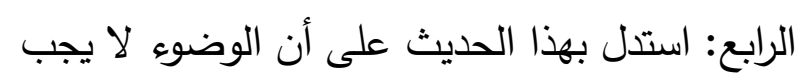

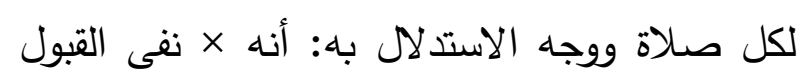

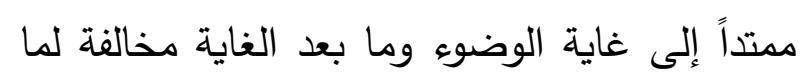

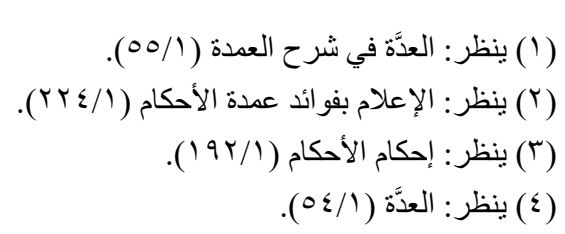


ا ـ تطبيق صيغة العموم في قوله ×: (شرب)، فيشمل

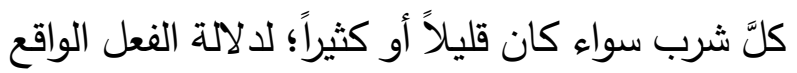
في سياق الشرط على العموم.

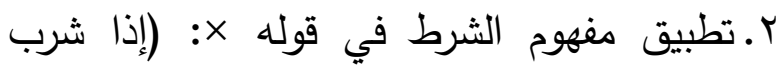

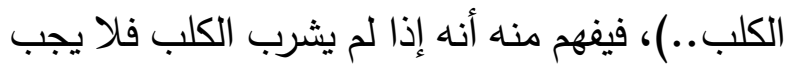
غسله سبع مرات. r. تطبيق صيغة العموم في قوله ×

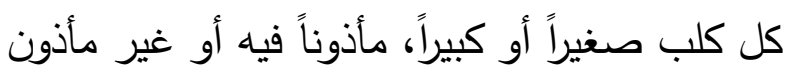
فيه، أسوداً كان أو غير ذلك؛ لداو كلالة (ال) الاستغراقية

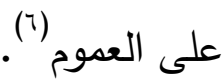
قال ابن دقيق العيد رحمه الله (ت:Y • Vهـ): "الحديث عام في جميع الكلام، وفي مذهب مالك قول يخصِّهـ بالمنهي عن اتخاذه، والأقرب العموم لأن الألف واللام إن لم يقم دليل على صرفها إلى المعهود

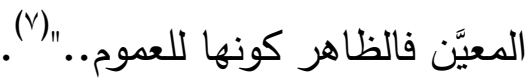

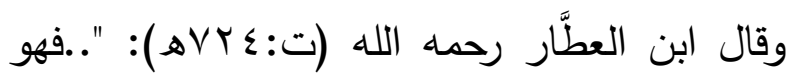
عام في كل كلب لعموم اللفظ، وهو مذهب جمهور العلماء، سواء كان مما يجوز اقتناؤه، وسواء كلب

$$
\text { البدوي والحضري.." (^). }
$$

ـ. تطبيق صيغة العموم في قوله ×: (إناء أحدكم)،

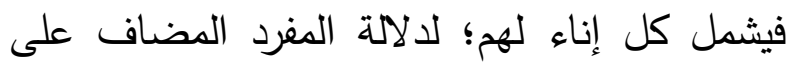

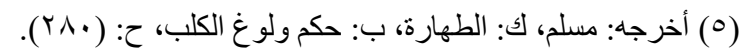

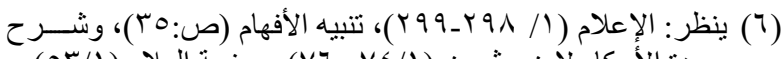

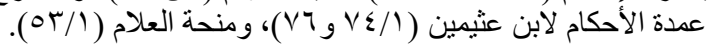

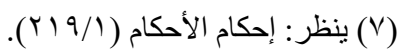

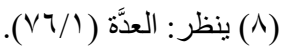

عام الفتح الصلوات الخمس بوضوء واحد فسأله عمر فقال: إنك صنعت اليوم شيئا لم تكن تفعله من قبل، قال: عمدا فعلت ذلك" ليبين جواز جمع الصلوات

$$
\text { بوضوء واحد" (') }
$$

الـ ـ تطبيق دلالة الاقتضاء في قوله ×: "لا يقبل الله صلاة أحدكم إذا أحدث حتى يتوضأ"، فالكلام يقتضي تقدير محذوف ضرورةً وهو لفظ (..ويصلي). قال ابن الملقِّن رحمه الله (ت:؟ ــهـ): "العاشر: لابد في الحديث من تقدير حذف وهو: لا يقبل الله

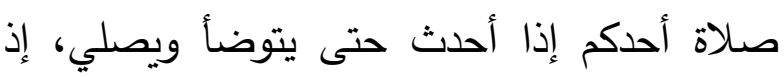
يستحيل قبول صلاة غير مقبولة"(؟). المطلب الثاني: التطبيق الأصولي على حديث: "إذا

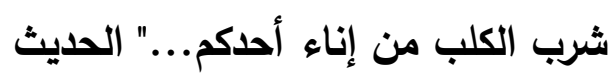

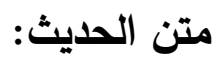

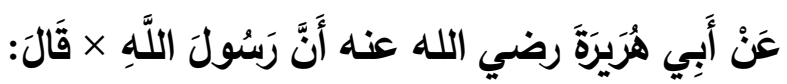

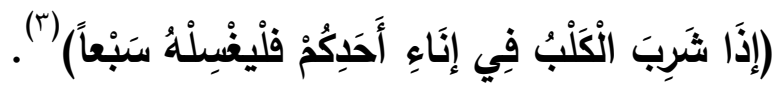

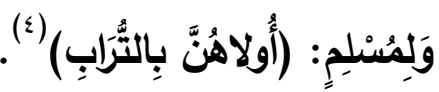

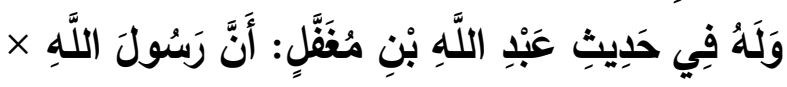

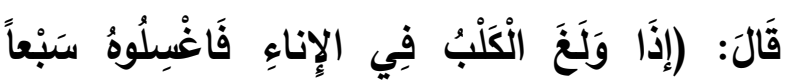

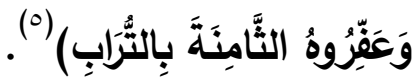
التطبيق الأصولي:

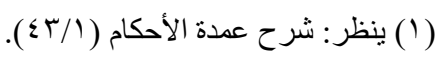

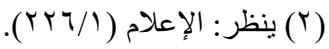

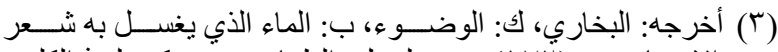

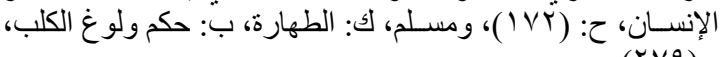

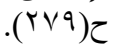
(§) أخرجه: مسلم، ك: الطهارة، ب: حكم ولوغ الكلب، ح: (YV9). 
الفور؛ لأن الأمر يقتضي الفورية عند أكثر الفقهاء، وهو المختار "(•). وقال السفاريني رحمه الله (ت:11 الهـ): "ظاهر قوله (فليغسله) يقتضي الفور لكن حمل الجمهور

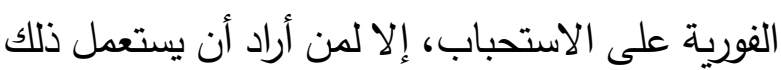

$$
\text { الإناء "(7) }
$$

^.تطبيق صيغة الإطلاق في قوله × (فليغسله)،

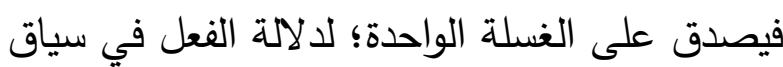

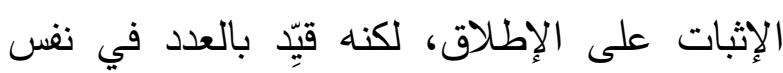
الحديث بقوله ×: (سبعاً). 9. تطبيق صيغة الخصوص في قوله ×: (سبعاً)؛ فإنه عدد، والأعداد من قبيل النصوص التي لا تحتمل

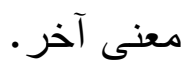
قال ابن دقيق العيد رحمه الله (ت: ب • Vه): "الحديث نص في اعتبار السبع في عدد الغسلات، وهو حجة على أبي حنيفة في قوله: يغسل ثلاثا"(V)

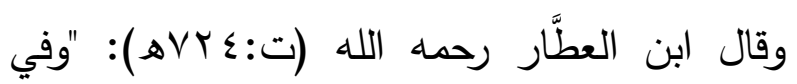
الحديث دليل نصا على اعتبار السبع في عدد الغسلات، وهو مذهب الثافعي، ومالك، وأحمد،

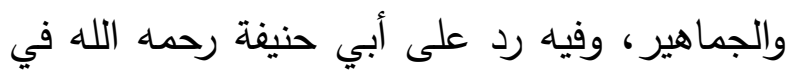

$$
\begin{aligned}
& \text { (0) ينظر : طرح التتريب (1) (1) (1) (1). }
\end{aligned}
$$

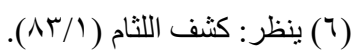

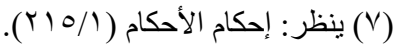

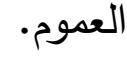
قال السفاريني رحمه الله (ت:11 (اهـ): "ظاهره العموم في كل آنية"(') ه.تطبيق صيغة العموم في قوله ×: (أحدكم)، فيشمل كل أحد سواء كان كبيراً أو صغيراً، غنياً أو أو فقيراً؛ لدلالة المفرد المضاف على العموم. 7. تطبيق صيغة الأمر في قوله × : (فليغسله)؛ لكونه فعلاً مضارعاً اقترن به لام الأمر .

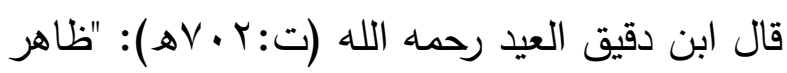
الأمر الوجوب، وفي مذهب مالك قول أنه

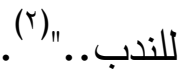
وقال ابن عثيمين رحمه الله (ت:ابله (هـ): "فليغسله: اللام للأمر "("). V. تطبيق اقتضاء صيخة الأمر للفورية في قوله ×: (فليغسله)، لكونه فعلاً مضارعاً اقترن به لام الأمر .

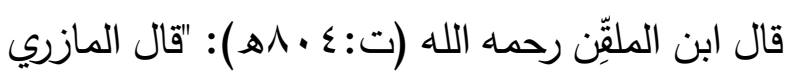

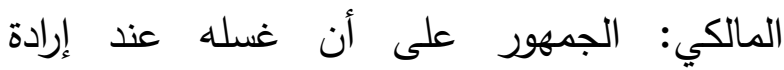
الاستعمال، وذهب بعض المتأخرين إلى غسله وإن

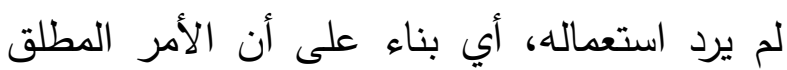

يقتضي الفورية" (؛). وقال زين الدين العراقي رحمه الله (ت:1 +1هـ):

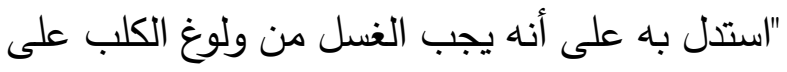


فمه أشرفها، فالباقي من باب أولى على الصحيح،

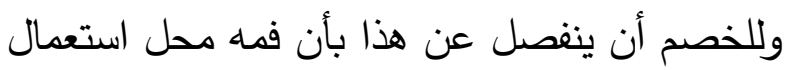

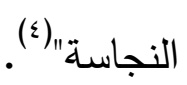

ع ا. تطبيق القياس الأولوي في الحديث: فيقاس بول الكلب وغائطه على لعابه بجامع التتجيس.

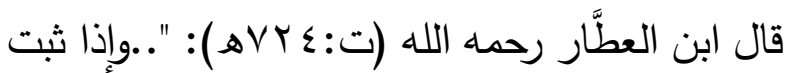

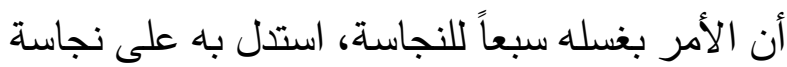
عين الكلب، إما لنجاسة لعابه المتصل بفهد، لكونه جزءاً منه، وفمه أشرف ما فيه، وهو نجس، إنجاسه لعكله نجس، أو لكون اللعاب نجساً، وهو عرَق الفم، فعرقه كله نجس، وهو متحلب من البدن، فجميعه نجس. فتبين من الحديث الدلالة على نجاسته فيما يتعلق بالفم، وفي باقي البدن بالاستتباط، وفيه بحث.."( (ه).

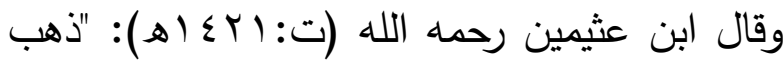
بعض العلماء إلى أن النجاسة المغلظة في لعاب الكلب فقط، لقوله (إذا شرب الكلب في إناء أحدكم) وأن بقية نجاسته كغيرها من النجاسات فبوله وروثه

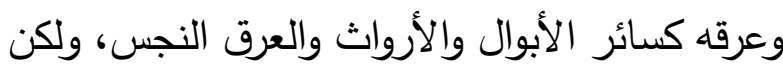

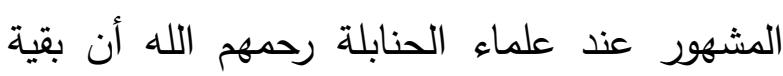
نجاساته كالنجاسة الحاصلة بريقه ولعابه، وقالوا: إن نجاسة البول والعذرة أقبح من نجاسة الريق، ومن

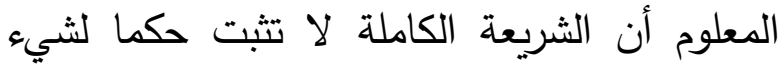
وتنفي هذا الحكم عن شيء أولى منه، وهذا القياس
قوله: تغسل ثلاثا، وكأنه لم يبلغه الحديث"(') وبنحوه قال ابن الملقِّن رحمه الله (r). • (. ـبيق مفهوم العدد في قوله ×: (سبعاً)،

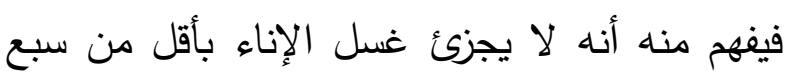

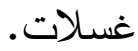
ال. تطبيق صيغة العموم في قوله ×: (ولغ)، فيشمل كل ولوغ سواء كان يسيراً أو كثيراً؛ لدلالة الفعل فئل الواقع في سياق الثرط على العموم. با. تطبيق مفهوم الشرط في قوله ×: (إذا ولغ)، فيفهم منه أنه إذا لم يلغ الكلب فلا يجب غعل فل فل الإناء

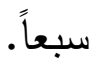
ץ ا. عدم تطبيق مفهوم الصفة في قوله ×: (ولغ)؛ لكونه خرج مخرج الغالب. قال زين الدين العراقي رحمه الله (ت: : ـ 1 هـ) : "إنما نص على الولوغ لكونه الغالب فيما تصيبه الكلاب من الأواني، فإنها إنما تقصد الأكل، والثرب من لنه الأواني فخرج بذلك مخرج الغالب لا مخرج الشرط" "َّا".

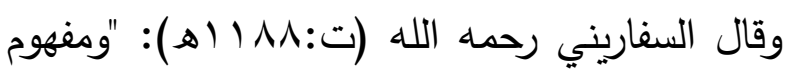
الشرط في قوله: (إذا ولغ) يقتضي قصر الحكم على ذلك، نعم: إذا قلنا إن الأمر بالغسل للتنجيس يتعدى إنى

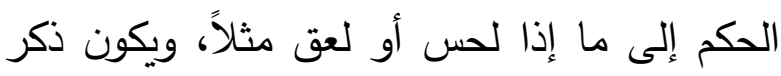

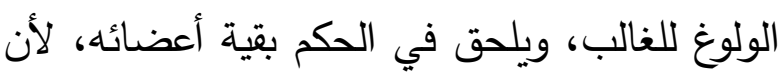

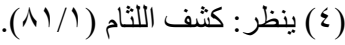

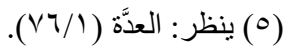


قال ابن عثيمين رحمه الله (ت:ابץ اهـ): "(في الإناء) خرج به ما لو ولغ في بركة أو ساقية أو ما أشبه ذلك" (Y). V V ا . تطبيق صيغة الأمر في قوله ×: (وعغّروه)؛ لكونه على وزن (افعل).

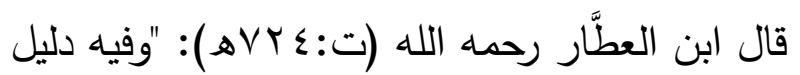
على وجوب التعفير بالتراب، وبه قال الثافعي

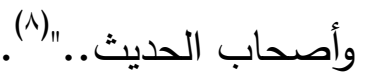

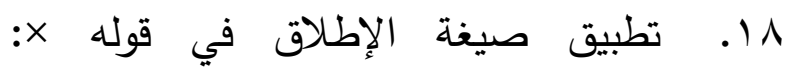
"وعفِروه"، فيصدق على صورة واحدة؛ لدلالة الفعل في سياق الإثبات على الإطلاق. 19. تطبيق صيغة الخصوص في قوله ×الإله (الثامنة)؛ فإنه عدد، والأعداد من قبيل النصوص فئه التي لا تحتمل معنى آخر . الته

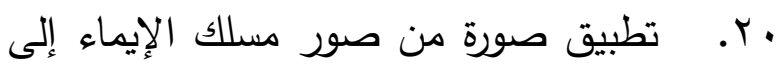
العلة وهي: ترتيب حكم على وصف بصيغة الثرط والجزاء، فالحكم وهو قوله: (فاغسلوه) رُتِّب على ترّي وصف وهو قوله: (إذا شرب الكلب) بصيغة الشرط والجزاء، فتكون علة الأمر بغسل الإناء هي: حصول لردل

$$
\text { الشرب من الكلب. }
$$

الذي ذهب إليه علماء الحنابلة أقرب إلى الصواب وأحوط وهو أن تجري جميع نجاسات الكلاب مجرى النه

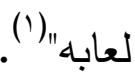
وقال رحمه الله: "إذا وجب التطهير من ولوغه بما ذكر، فالتطهير بذلك من بوله وعذرته ونحوهما من

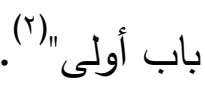
10. تطبيق صيغة العموم في قوله ×: (الإناء)، فيشمل كل إناء سواء كان صغيراً أو كبيراً، أو كان إناء ماء أو إناء طعام (r)؛ لدلالة (ال) الاستغراقية على العموم. - ماء. قال ابن دقيق العيد رحمه الله (ت:r • Vه): "عام

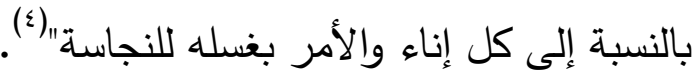

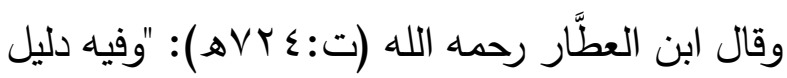

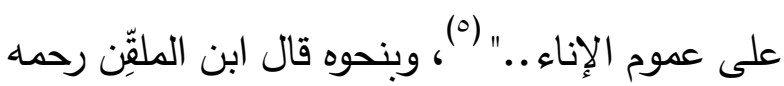
الله (). 17. الطبيق مفهوم الظرف في قوله ×: "في الإناء"، فيفهم أنه إذا شرب الكلب في غير إناء كبئر أو نهر فلا يجب غسله سبع مرات.

\footnotetext{
(1) ينظر : شرح عمدة الأحكام (1/1) (1).

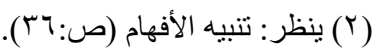

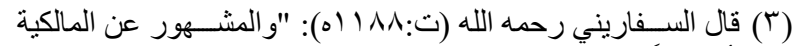

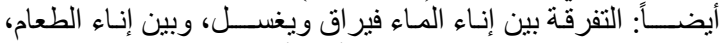

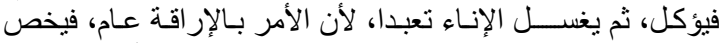

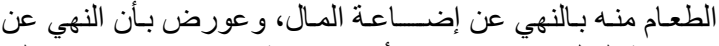

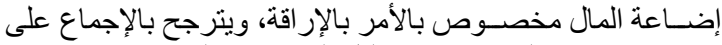

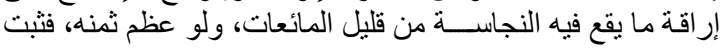

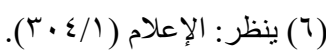

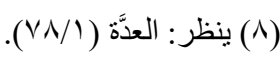


التصحيح، والمجد في شرحه، وتصحيح المحرر، لأن

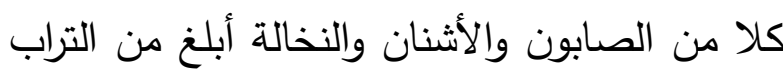
في الإزالة، فنصه على التراب تتبيه عليها، ولأن

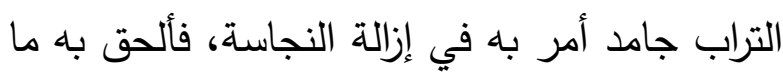
يماثله، كالحجر في الاستجمار ، وقيل: لا يجزئه، لأنه

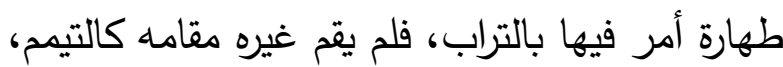

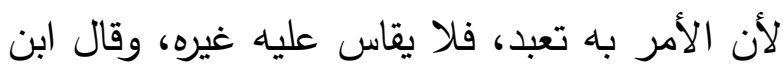

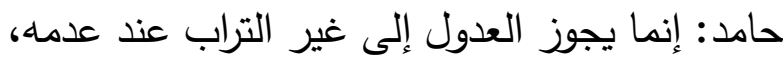

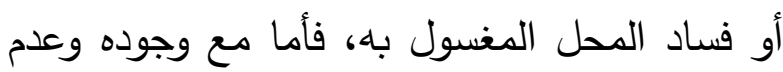

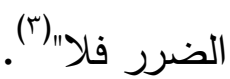

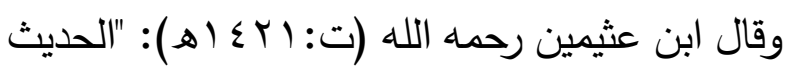
نص في وجوب التطهير بالتراب مع الماء، فلا يطهَّر بغير ذلك إلا إذا تعذر "(£). وقال عبدالله الفوزان حفظه الله: "الحديث نص في لـي وجوب التطهير بالتراب مع الماء، لخبث نجاسة الكلب، وهو قول الثافعية والحنابلة ولا فرق بين أن بأن

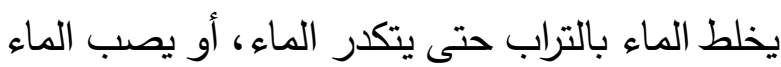

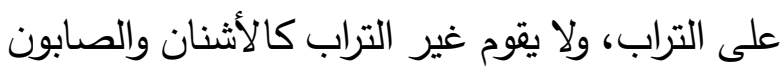

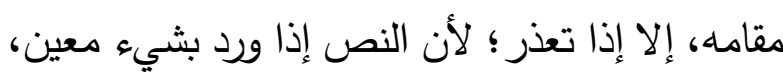
واحتمل معنى يختص بذلك الثيء لم يجز إلغاء النصوص وترك ما عُيْنَ فيها. والأمر بالتراب، وإن كان يحتمل أنه لزيادة التنظيف،

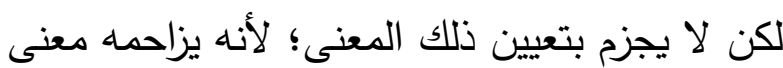

ا ا. تطبيق صيغة الخصوص في قوله ×:

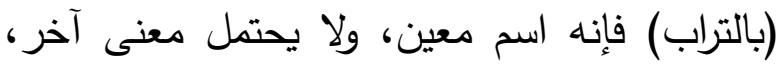
وخالف في ذلك بعض العلماء رحمهم الله تعالى. قال ابن دقيق العيد رحمه الله (ت:Y • Vه): "قوله: بالتراب يقتضي تعينه، وفي مذهب الثافعي قول أو وجه: إن الصابون والاثنان والغسلة الثامنة تقوم مقام

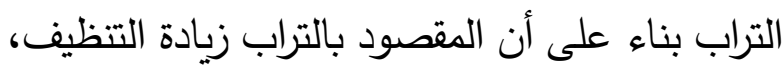

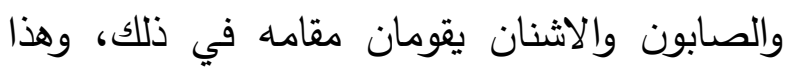
عندنا ضعيف؛ لأن النص إذا ورد بشيء معين واحتمل معنى يختص بذلك الثيء لم يجز إلغاء

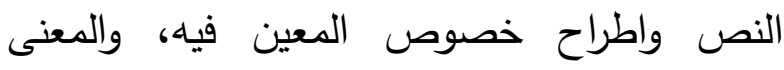
المستنبط إن عاد على النص بالإبطال أو التخصيص فهو مردود عند جمع من الأصوليين"|(')

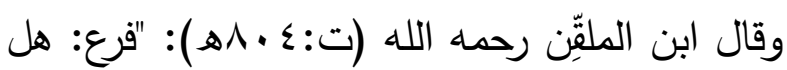
الأمر بالتراب تعبد محض لا يعقل معناه، أو معلَّل بالاستطهار بغير الماء ليكون فيه زيادة كلفة وتغليظ، لهاهل

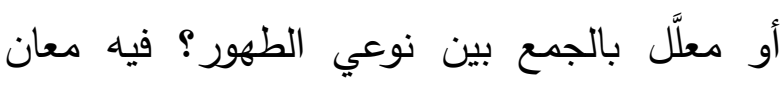
استنبطها أصحابنا وليس فيها سوى مجرد مناسبة ليس بلي

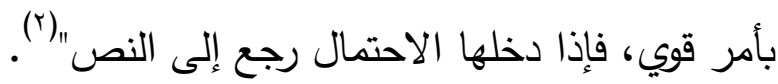

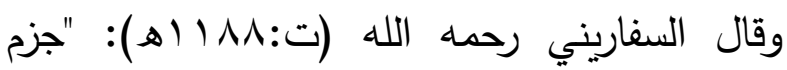
علماؤنا بإقامة نحو الأشنان مما له قوة الإزالة مقام التراب، لا غسلة ثامنة، قال شيخ الإسلام ابن تيمية

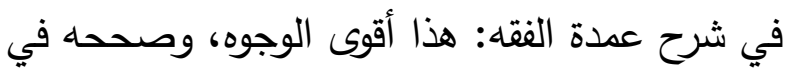

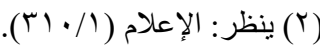


والمشهور من مذهب مالك والقوي من جهة الدليل وهو قول أكثر العلماء كما عزاه النووي في شرح مسلم" (๕) وقال عبدالله الفوزان حفظه الله: "تعدد الغسلات خاص بنجاسة الكلب، ولا يقاس عليه غيره كالخنزير؛ لأن العبادات توقيفية، وهذه أمور لا تدرك بالرأي

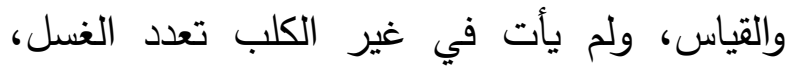

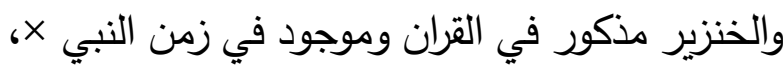
ولم يرد إلحاقه، فنجاسته كنجاسة غيره.

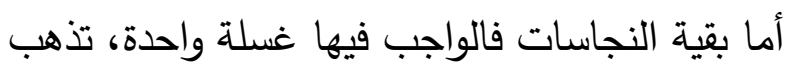
بعين النجاسة وأثرها، فإن لم تذهب زاد حتى يذهب

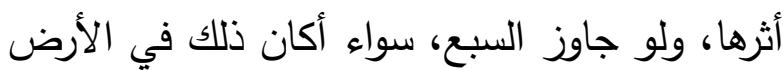

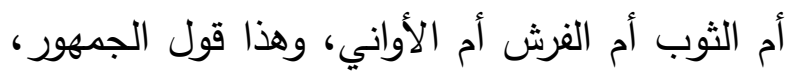
لقوله ×: إإذا أصاب إحداكن الدم من المن الحيضة

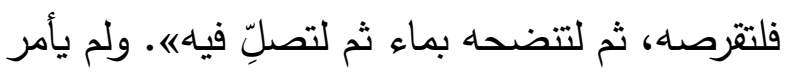
فيه بعدد، ولو أراده لبينه، كما في حديث الولوغ، ولأن المقصود إزالة النجاسة، فمتى زالت زال حكمها" (ه). المطلب الثالث: التطبيق الأصولي على حديث: "لولا أن أثق على أمتي..." الحديث: التطبق الاصول

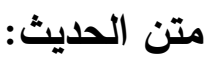

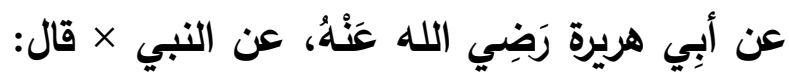

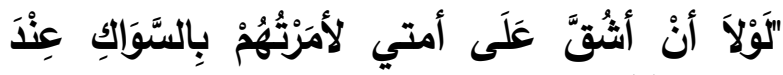

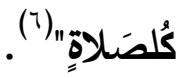

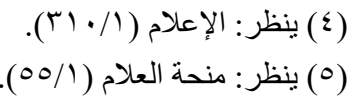

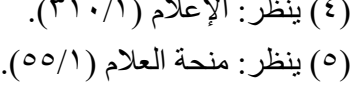

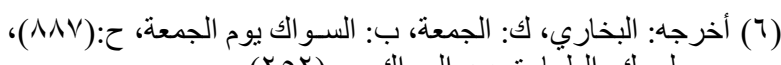

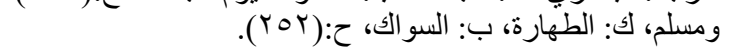

آخر وهو الجمع بين مطهرين: الماء والتراب، وهذا

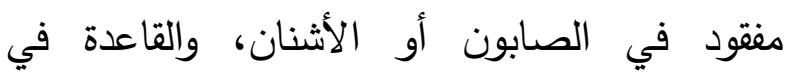

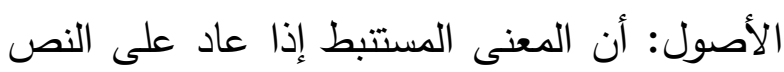

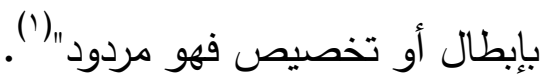

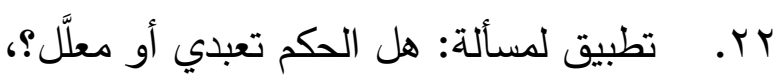
فيرى الإمام مالك أن الحكم تعبدي؛ لاعتقاده طهارة الماء والإناء لكون الكلب عنده طاهر ، ويرى الجمهور

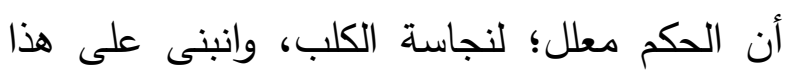
الخلاف مسائل منها: الخلاف في قياس الخنزير على لهى

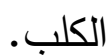

قال ابن دقيق العيد رحمه الله (ت:Y • Vه): "وحمل

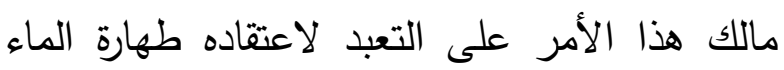

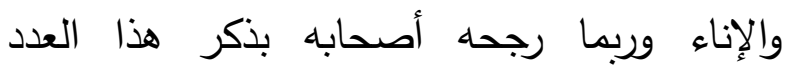
المخصوص وهو السبع لأنه لو كان للنجاسة: لاكتقى الإنى

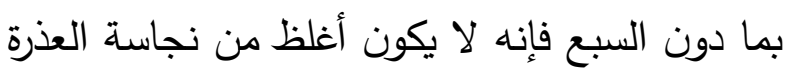

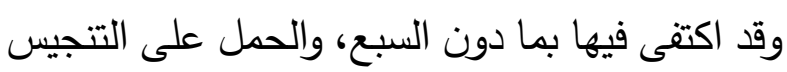

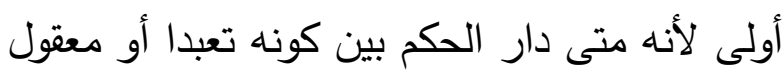
المعنى كان حمله على كونه معقول المعنى أولى لـى لدانه

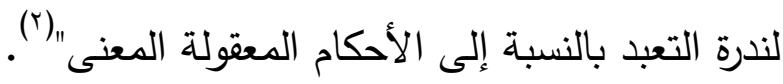
وبمثله قال ابن العطار رحمه الله (־ّ).

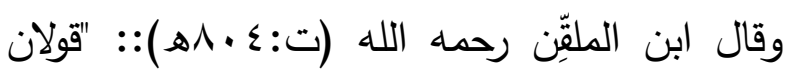
منشأهما: هل الغسل تعبد فلا يقاس على الكلب غيره،

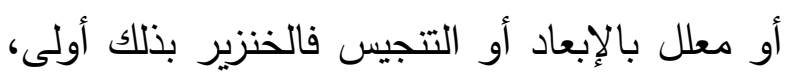

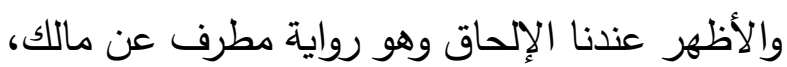

$$
\text { (1) (1) ينظر : منحة العلام (1) (ب7/1). }
$$

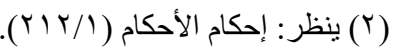

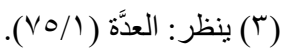




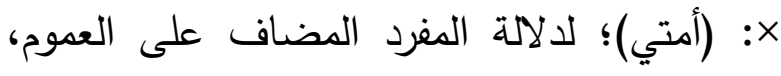

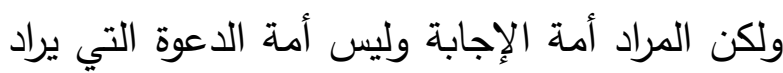
بهم كل من أرسل إليهم النبي ×.

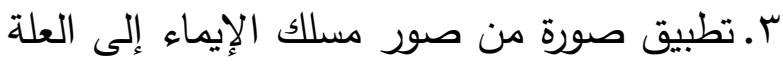
وهي: تعليل عدم الحكم بوجود المانع منه، وبيان ذلك:

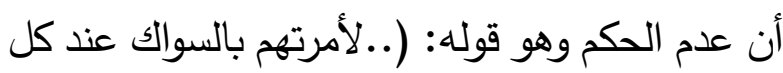

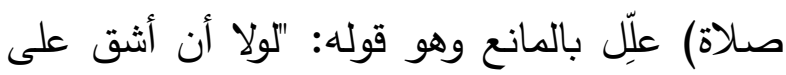
أمتي"، فتكون علة عدم إيجاب السواك عند كل صلع صلاة

$$
\text { وجود المشقة. }
$$

قال ابن الملقِّن رحمه الله (ت:؟ـ ـ1هـ): "فيه دلالة أيضا لمسألة خامسة أصولية: وهي جواز تعليل الحكم

$$
\text { العدمي بالمانع.."( ع). }
$$

ـ.تطبيق طريقة من طرق معرفة الحكم التكليفي وهي: امتتاع النبي × عن إيجاب السواك على أمته خوف المشقة عليهم، فلََّ على استحبابه لهم. ه. تطبيق مسألة جواز الاجتهاد للنبي × في بيان الأحكام الشرعية، وأنه إذا أُقِرَّ من الله تعالى على لهاديه فيكون تشريعاً لأمته.

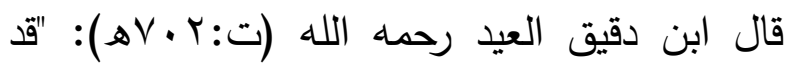

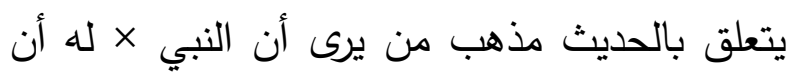
يحكم بالاجتهاد ولا يتوقف حكمه على النص فإنه جعل المشقة سبيا لعدم أمره ×، ولو كان الحكم موقوفاً

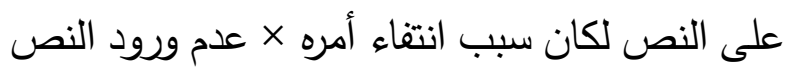

\section{التطبيق الأصولي:}

ا.تطبيق صيغة العموم في قوله ×: "كل صلاة" فيشمل كل صلاة؛ لالالة لفظ (كل) على العموم.

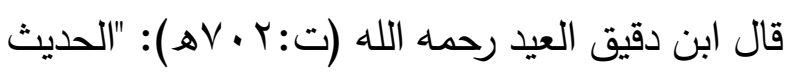
بعمومه يدل على استحباب السواك عند كل صلاة،

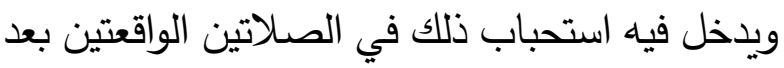

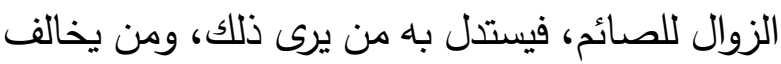
في ذلك يحتاج إلى دليل خاص بهذا الوقت يخص به به بـ دئ ذلك العموم، وهو حديث الخلوف، وفيه بحث" ('). وقال ابن الملقِّن رحمه الله (ت: ـ • هـه) : "في دلالة أيضا على مسألة فقهية: وهو استحباب السوالك عند كل صلاة سواء كانت فريضة عينا أو كفاية أو نافلة

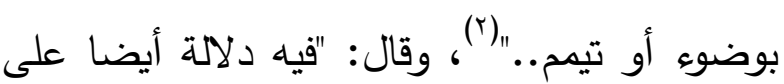

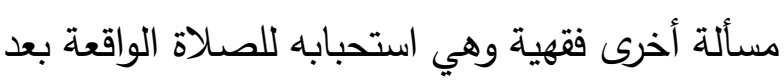

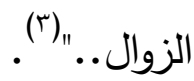

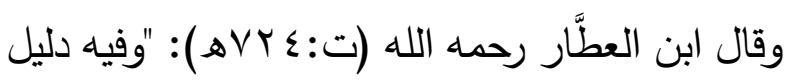

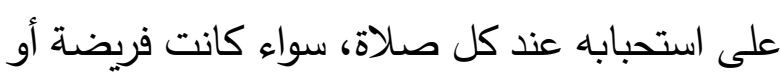
نافلة، متكررة في زمان: كالتراويح والضحى، أو الو كأه متفرقة: كالفرائض وتحية المسجد وسنة الوضوه...، وفيه دليل بعمومه على استحبابه للصلاة الواقعة بعد

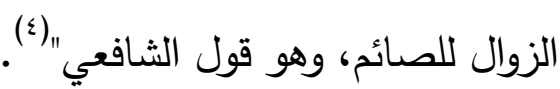
r. تطبيق صيغة عموم يراد بها الخصوص في قوله 
استتابته الاستفتاء عن غيره.

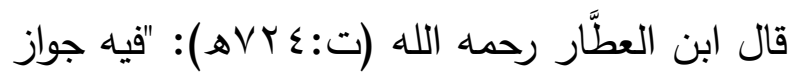
الاستتابة في الاستفتاء للعذر سواء كان المستفتي حاضراً أو غائباً.."(V) r. تطبيق صيغة التعليل في قول الراوي: "لمكان ابنته مني"، فعلة الاستحياء من سؤال رسول الله × هي: كونه زوج ابنته؛ لدلالة اللام على التعليل.

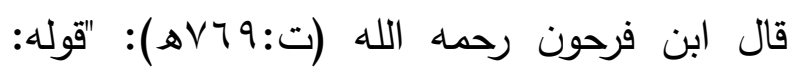
(لمكان ابنته): "اللام" لام العلة" (^)

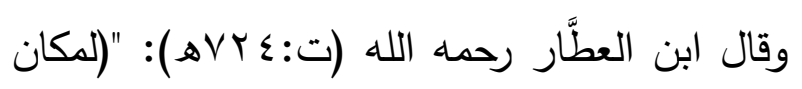

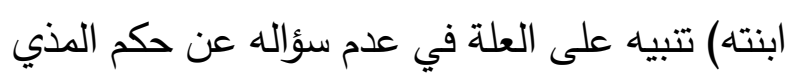
بنفسهة" (9) وقال ابن الملقِّن رحمه الله (ت:؟ • بهـ): "قوله

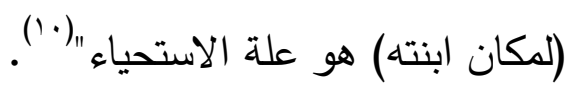

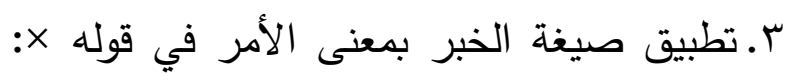

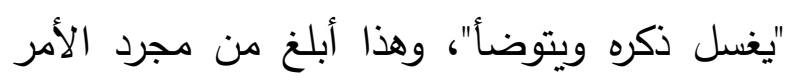

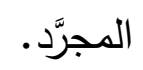
قال ابن دقيق العيد رحمه الله (ت: · • Vهـ): "(يغسل ذكره) برفع اللام على صيغة الإخبار ، وهو استعمال لصيغة الإخبار بمعنى الأمر، واستعمال الإخبار

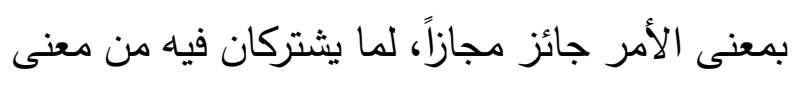

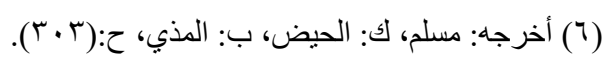

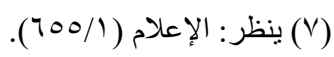

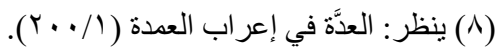

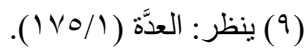

$$
\begin{aligned}
& \text { (1) (1) ينظر : الإعلام (1) (70/1). }
\end{aligned}
$$

به، لا وجود المشقة، وفيه احتمال للبحث والتأويل"(').

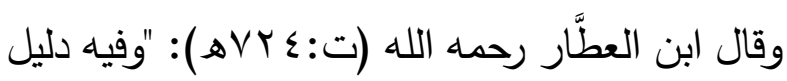
على جواز الاجتهاد للنبي ×، فيما لم يرد فيه نص رهل من الله تعالى، وهو مذهب الفقهاء، وأصحاب الأصول، وهو الصحيح المختار عندهم"(ب).

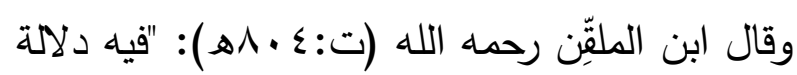

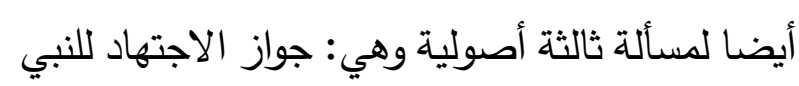

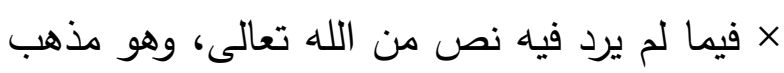
الفقهاء وأصحاب الأصول وهو الصحيح المختار عندهم" (r) المطلب الرابع: التطبيق الأصولي على حديث: "يغسل ذكره ويتوضأ". متن الحديث:

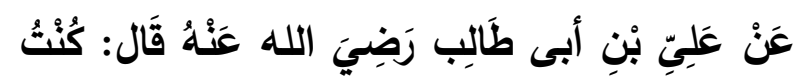

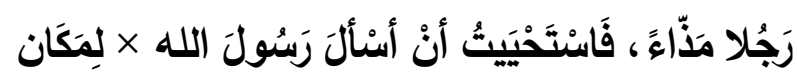

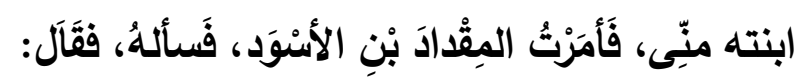

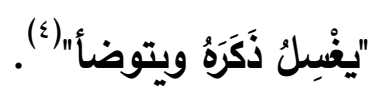

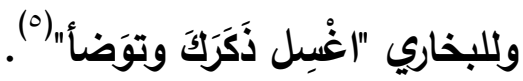

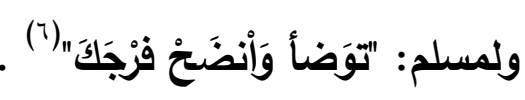
التطبيق الأصولي: ا ـ تطبيق دلالة إقرار النبي × للمقداد رضي بالله عنه

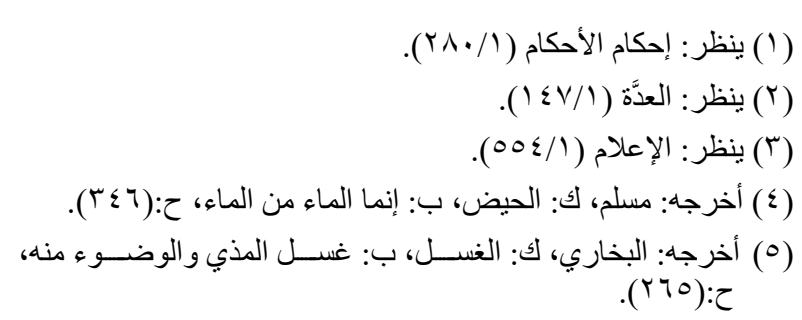


عنها وهي: "كنت رجلا مذاء..فسأله"، فتكون علة الأمر بغسل الذكر والوضوه هي: نزول المذي.

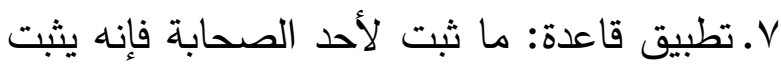
لغيره إلا بدليل يدل على التخصيص، فما ثبت لعلي

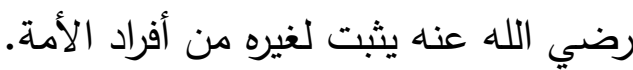

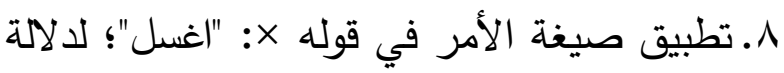
صيغة (افعل) على طلب الفعل.

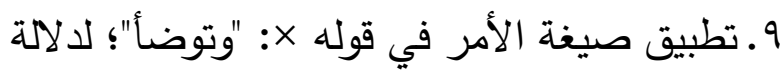
صيغة (افعل) على طلب الفعل. • ا. تطبيق صيغة الأمر في قوله × " "وانضح"؛ لالالة صيغة (افعل) على طلب الفعل. 11. تطبيق صيغة الإطلاق في قوله ×: "وانضح" يصدق بصورة واحدة، لدلالة الفعل الواقع في سياق الإثبات على الإطلاق. rا. تطبيق صيغة الإجمال في قوله ×ال "وانضح"، فإنه يطلق على الغسل وعلى الرش، وقد

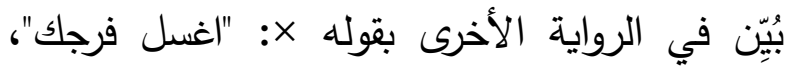
فيُحمل النضح هنا على الغسل. قال ابن دقيق العيد رحمه الله (ت:Y م.Vه): "(وانضح) يراد به: الغسل ههنا، والله أعلم، لأنه

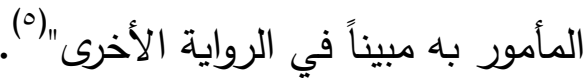

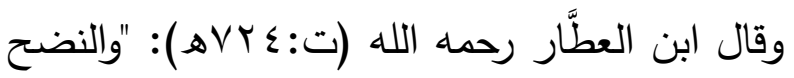
يكون غسلاً ويكون رشاً لكن الغسل هنا متعين ببيان
الإثبات للشيء"(') وبنحوه قال ابن العطار (؟) وابن الملقِن (r) رحمهما الله. وقال السفاريني رحمه الله (ت:11 1 (هـ): "هل يجوز

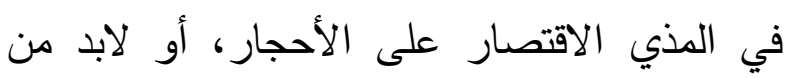

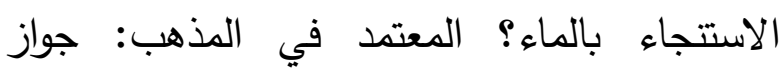
الاقتصار على الأحجار في الخارج دون الذكر والأنثيين، وصحح ابن دقيق العيد عدم الجواز، الهن كالنووي في شرح مسلم، وصحح في بقية كتبه الجواز ،

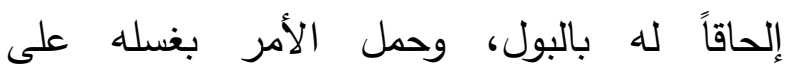

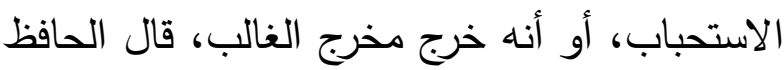
ابن حجر في شرح البخاري: وهذا هو المعروف في المذهب، يعني مذهب الثافعي، والله أعلم" (๕). ـ. تطبيق صيغة الإطلاق في قوله ×: "يغسل ذكره"، فيصدق بصورة واحدة؛ لدلالة الفعل الواقع في سياق لاق لاقل الإثبات على الإطلاق. 0.تطبيق صيغة الإطلاق في قوله ×: "ويتوضأ" فيصدق بصورة واحدة؛ لدلالة الفعل الواقع في سياق الإثبات على الإطلاق. 7. تطبيق صورة من صور الإيماء إلى العلة وهي: ترتيب حكم على واقعة مسؤول عنها فيدل على أن إن إن ما في السؤال من أوصاف هو العلة، وبيانه: أن قوله "يغسل ذكره ويتوضأ" حكم زُتِب على واقعة مسؤول 
التطبيق الأصولي:

ا.تطبيق دلالة الاقتضاء في قوله ×: (إن الله لا

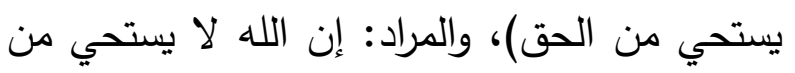
ذكر الحق. قال ابن دقيق العيد رحمه الله (ت: ب • Vه): "الأقرب

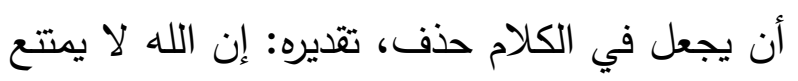
من ذكر الحق، والحق ههنا خلاف الباطل.."(') .

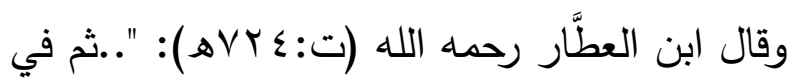
الكلام حذف، تقديره: إن الله لا يستحيي من ذكر آله

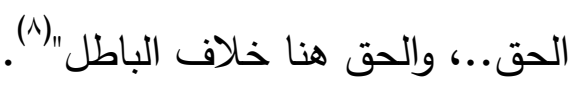

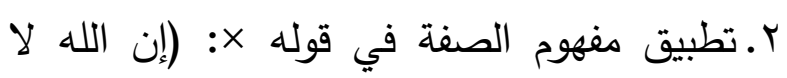

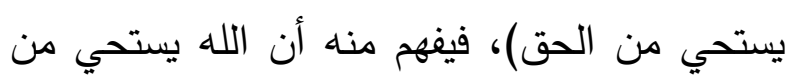
ذكر غير الحق وهو الباطل.

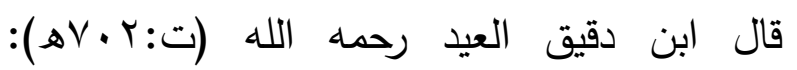
"..وبطريق المفهوم: يقتضي أنه يستحيي من غير لهين الحق"(9). وبمثله قال ابن العطار (·') وابن الملقِّن

رحمهما الله ('). ץ. تطبيق صيغة العموم في قوله ×: (المرأة)، فيشمل كل امرأة؛ لدلالة (ال) الاستغراقية على العموم.

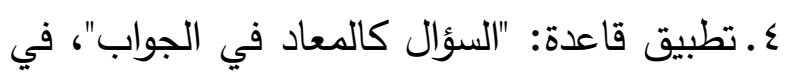

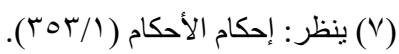

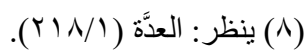

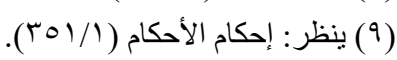

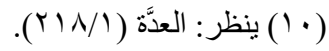

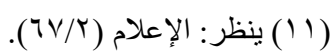

الرواية الأخرى في الأمر به، فحمل النضح عليه"|'.

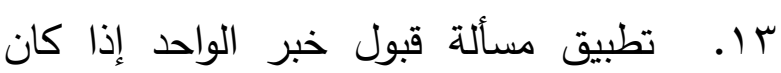
المخبر ثقة، كما حصل للمقداد رضي الله عنه عندما أرسله علي رضي الله عنه وأقرهما النبي ×ذلك.

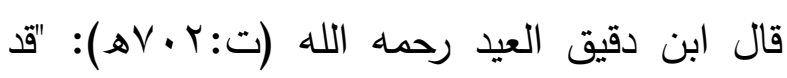
يتمسك به - أو تمسك به - في قبول خبر الوبل رحاحد من حيث إن عليا رضي الله عنه أمر المقداد بالسؤال ليقبل خبره والمراد بهذا: ذكر صورة من الصور التي

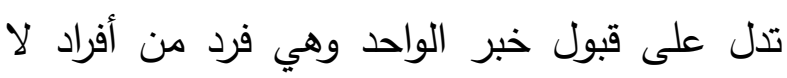

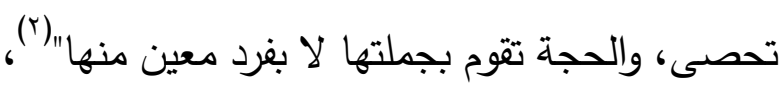

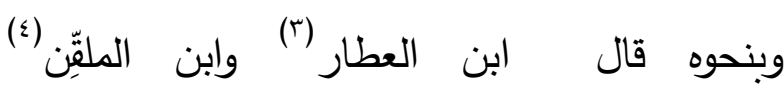
والسفاريني (0) رحمه الله. المطلب الخامس: التطبيق الأصولي على حديث:

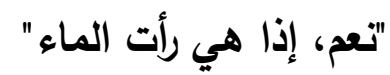
متن الحديث:

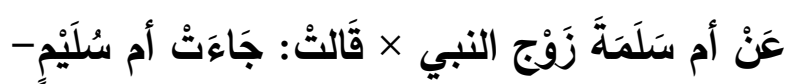

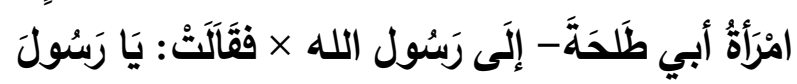

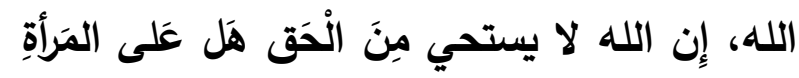

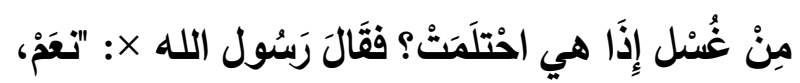

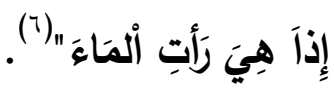

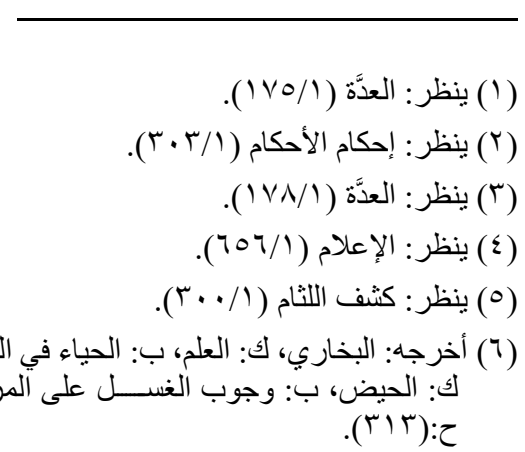


قال ابن عثيمين رحمه الله (ت:إبـ (أه): "أن النبي

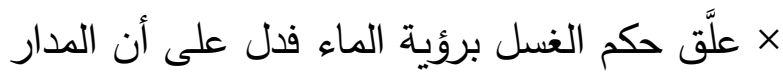

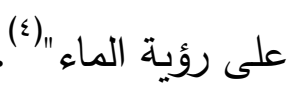

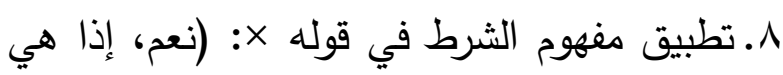

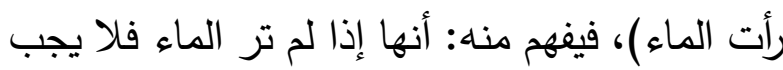

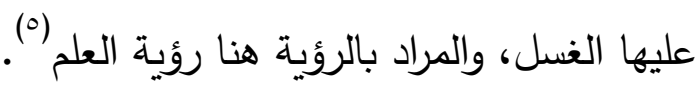
قال ابن فرحون رحمه الله (ت:979 هـ): "والرؤية يحتمل أن تكون علمية، فتتعدى إلى مفعولين، والثاني

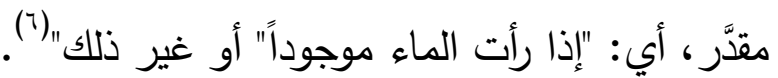
9. تطبيق أدب من آداب الاستفتاء في قول أم سليم: (هل على المرأة من غسل إذا هي احتلمت؟...)، وهو:

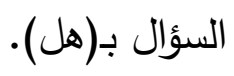

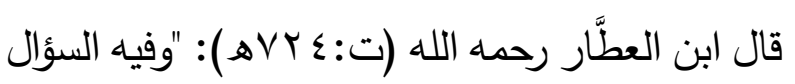
في الاستفتاء: بهل، تتبيها على عدم معرفة السائل،

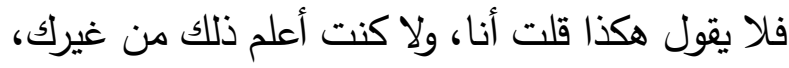
أو قال فلان: بخلاف قولك" "(v) . وبمثله قال ابن الملقِّن

رحمه الله (^).

المطلب السادس: التطبيق الأصولي على حديث:

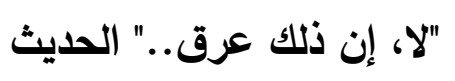
متن الحديث: - م عَن عَائشََةَ رَضِيَ الله عَنهَا: أنَّ فَاطِمَةَ بِنْتَ أبي
قوله ×: (نعم) أي: نعم، عليها الغسل إذا هي

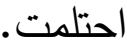

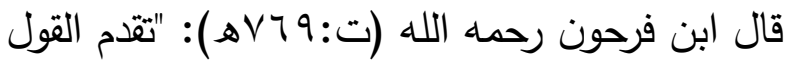
على "نعم"..، و "إذا" تقدمت في الثاني من الأول، وجوابها هنا محذوف يدل عليه ما قبله، أي: "إذا لها احتلمت فعليها الغسل"، ولو اقتصر القول على "نعم"

أغنت عن "إذا" وجوابها" (').

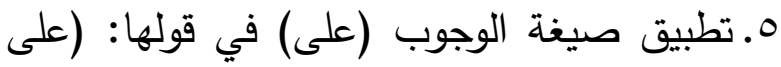

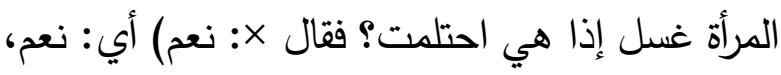

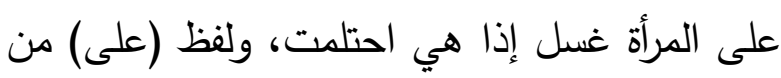

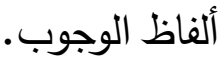

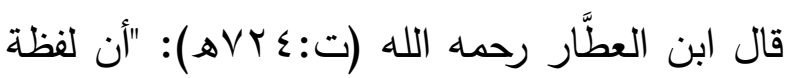
(على) مقتضاها: الوجوب"(؟) ، وبمثله قال ابن الملقِّن رحمه الله (r). 7. تطبيق قاعدة: ما ثبت لأحد الصحابة فإنه يثبت لغيره إلا بدليل يدل على التخصيص، فما ثبت لأم

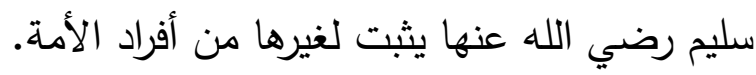

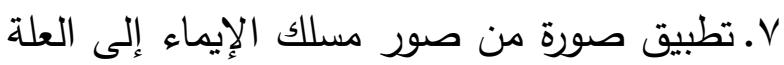
وهي: ترتيب حكم على وصف بصيغة الشرط

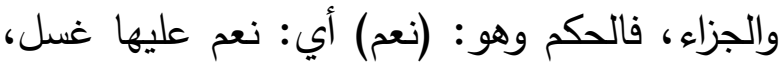
وقد رُتّب على وصف وهو: (إذا هي رأت الماء)، فتكون علة وجوب الغسل: رؤية المني. 
الحكم بعدم ترك الصلاة وقت الاستحاضة: كونه دم عرق.

7. تطبيق صيغة الخصوص في قوله ×: (ذلك)؛ لكونه اسم الإشارة، وأسماء الإشارة نصوص لإنه لا تحتمل

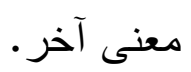
V.تطبيق صيغة الأمر في قوله ×: (دعي)؛ لدلالة صيغة (افعل) على طلب الفعل. ^.تطبيق صيغة العموم في قوله ×اءئ (الصلاة)

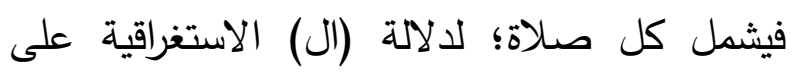

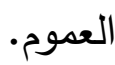

9. تطبيق صيغة العموم في قوله ×: (الأيام التي كنت تحيضين فيها)، فيشمل كل الأيام التي كانت تحيض فيها؛ لدلالة (ال) الاستغراقية على العموم. • ا. تطبيق صيغة الأمر في قوله ×: (اغتسلي)؛ لدلالة صيغة (افعل) على طلب الفعل. ا1. تطبيق صيغة الأمر في قوله ×: (وصلي)؛ لالالة صيغة (افعل) على طلب الفعل. r ا. تطبيق صيغة العموم في قوله ×: (أقبلت)، فيشمل كل إقبال للحيضة، لدلالة الفعل الواقع في سياق الثرط على العموم.

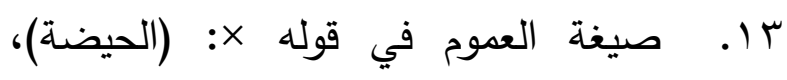

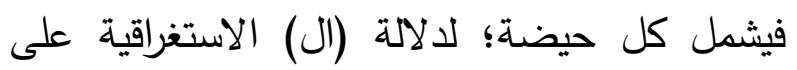

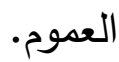
ع ا. تطبيق صيغة الأمر في قوله ×: (فاتركي)؛

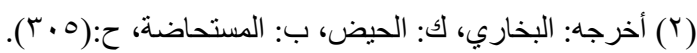

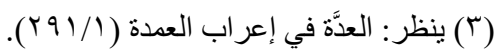

حُبيُش سَألتِ النَّبَّيَ ×، فقالت: إني أُسْتَحَاضُ فلا

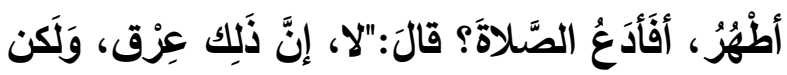

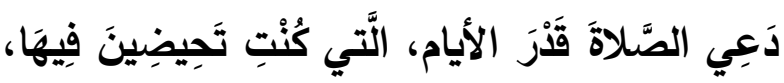

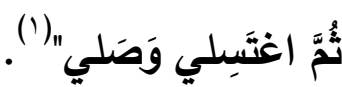

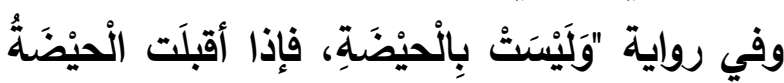

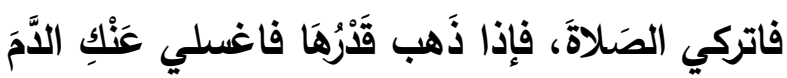

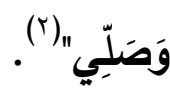
التطبيق الأصولي: ا. تطبيق قاعدة: "ما ثبت لأحد الصحابة فإنه يثبت لغيره إلا بدليل يدل على التخصيص"، فما ثبت لفاطمة رضي الله عنها يثبت لغيرها من أفراد الأمة. r.تطبيق صيغة العموم في قوله ×: (فلا أطهر)،

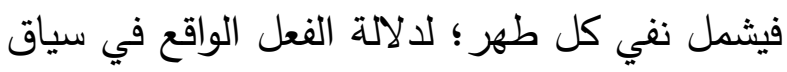

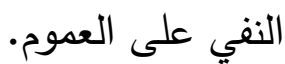
ץ.تطبيق صيغة العموم في قوله × (الصلاة)،

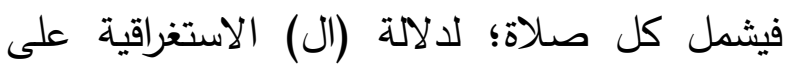

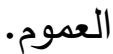
ـ ـ تطبيق قاعدة: "السؤال كالمعاد في الجواب"، في قوله ×: (لا) أي: لا تدع الصلاة وقت الاستحاضة.

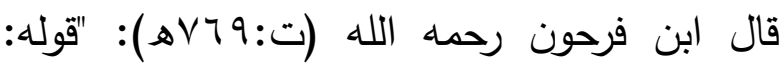
(فقال: لا) حرف جواب، كما تقول: نعم،...فالتقدير :

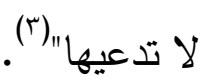
ه. تطبيق صيغة التعليل في قوله ×: (إنَّ)، فعلة (1) أخرجه: البخاري، ك: الحيض، ب: إذا حاضـــت في شـــهر ثلاث

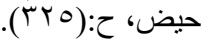




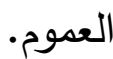

قال ابن عثيمين رحمه الله (ت: ابץ؟ (هـ): "لا يعفى عن يسير دم الحيض لعموم قوله (فاغسلي عنك الدم)

فتغسل ولو كانت نقطة يسيرة"(£) اب. تطبيق صيغة الأمر في قوله ×: (وصلي)؛ لدلالة صيغة (افعل) على طلب الفعل.

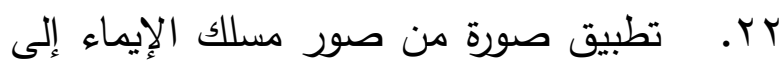

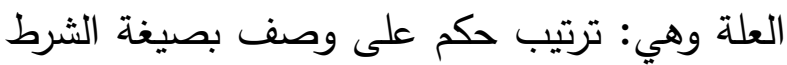
والجزاء، فالحكم وهو: (فاغسلي عنك الدم وصلي)،

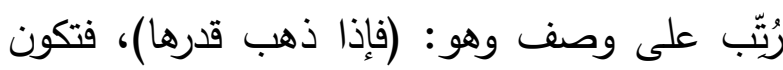
علة الأمر بغسل الام والصلاة: ذهاب زمن وهن الحيض. rr. تطبيق مفهوم الشرط في قوله ×: (فإذا ذهب دهن قدرها فاغسلي عنك الدم وصلي)، يفهم منه: أنه إذا لم يذهب زمن الحيض فلا تغسل ولا تصلي. ؟ Y. تطبيق لقاعدة: "ترك الاستفصال في مقام

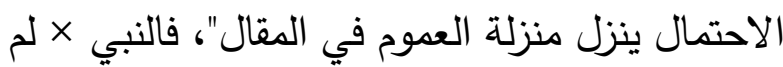
يستصصل منها هل هي ممن تميّز الدم أولا؟ وإنما

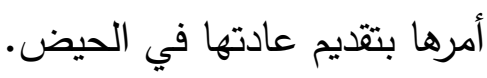

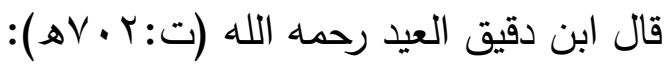
"..وليس في هذا اللفظ الذي في هذه الرواية ما يدل

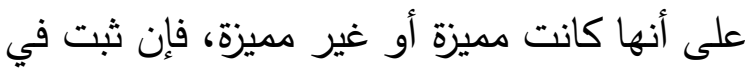
هذا الحديث رواية أخرى تدل على التمييز ليس لهاني معارض فذاك، وإن لم يثبت فقد يستدل بهذه الرواية
لدلالة صيغة (افعل) على طلب الفعل. 10. تطبيق صورة من صور مسلك الإيماء إلى العلة وهي: ترتيب حكم على وصف بصيغة الشرط والجزاء، فالحكم وهو : (فاتركي الصلاة)، رُتبّب على لى على وصف وهو: (فإذا أقبلت الحيضة)، فتكون علة الأمر بترك الصلاة: وجود الحيض. 17 . تطبيق مفهوم الشرط في قوله ×: (فإذا أقبلت الحيضة فاتركي الصلاة)، فيفهم منه: أنه إذا لم تقبل الحيضة فلا تتركي الصلاة. قال ابن دقيق العيد رحمه الله (ت:Y • Vهـ): "وقوله:

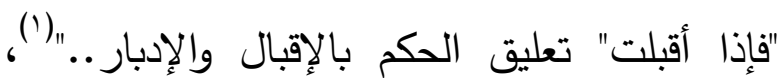

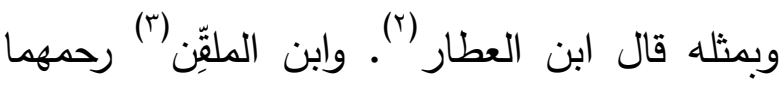

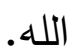
IV

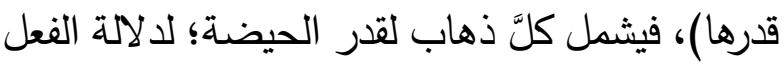
الواقع في سياق الثرط على العموم.

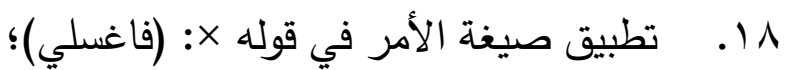
لدلالة صيغة (افعل) على طلب الفعل. 19. تطبيق صيغة الإطلاق في قوله ×: (فاغسلي)؛ لدلالة الفعل الواقع في سياق الإثبات لكنه مقيَّد بقوله (الدم) فيُغسَل الدم. •r. . تطبيق صيغة العموم في قوله ×: (الدم)،

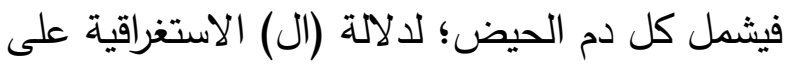


وتتزيل الأحكام.

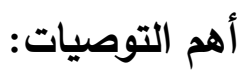

ا ـالاعتناء بالنصوص الثرعية عموماً والسنة

خصوصاً لإقامة البحوث والدراسات حولها.

r.الاهتمام بالتطبيقات الأصولية وإبراز أثر علم لماتهات أصول الفقه في المسائل والأحكام.

ץ.إجراء دراسة متخصَّصة في التطبيق الأصولي وبيان شروطه وضوابطه وأدواته ومهاراته.

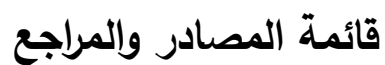

القرآن الكريم، برواية حفص عن عاصم،

مجمع الملك فهد لطباعة المصحف الثريف. لرون ا • الإبهاج في شرح المنهاج ، لشيخ الإسلام علي بن عبدالكافي السبكي ، (ت: : تاج الدين عبدالوهاب بن علي السبكي ، ت :

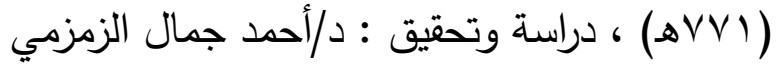

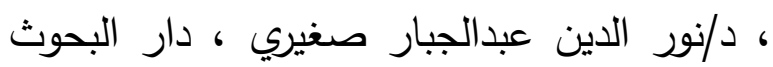

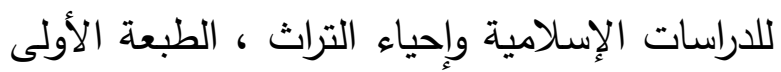
. D ا I $\leqslant \varepsilon$

r. إحكام الأحكام في شرح أحاديث الأحكام، إملاء الحافظ تقي الدين محمد بن علي بن وهب القشيري المعروف بـ(ابن دقيق العيد) المالكي ثم بث بن الثافعي، تحقيق: عبدالمجيد بن خليل العمري

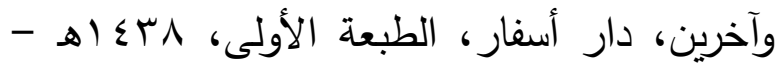
.
من يرى الرد إلى أيام العادة سواء كانت مميزة أو

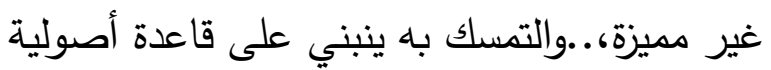
وهي ما يقال: إن ترك الاستفصال في قضايا

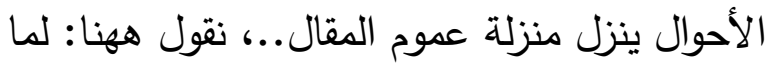
سألت هذه المرأة عن حكمها في الاستحاضة، ولم عنمال

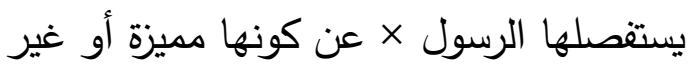

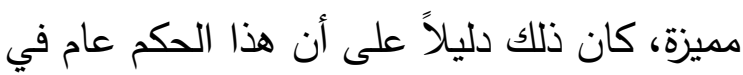

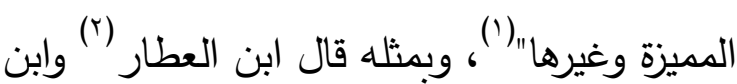

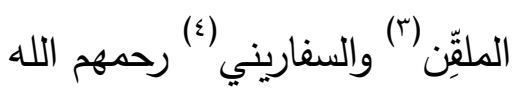

\section{الخاتمة}

في ختام هذا البحث أحمد الله تبارك وتعالى على تيسيره وعظيم امتنانه، وأسأله سبحانه أن يرزقنا العلم النافع والعمل الصالح، وقد توصلت لجملة من النتائج والتوصيات من أهمها: أهم النتائج: ا ـ أهمية علم أصول الفقه وعظم شأنه وخطورة أمره، إذ هو أداة الاستتباط من الكتاب والسنة وبه يتم

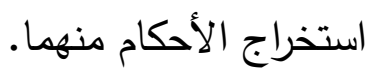
r.كثرة التطبيقات الأصولية التي تشتمل عليها النصوص الثرعية، مما يبين عظم أثر علم أصول الفقه في الأحكام الفقهية. r. مراعاة العلماء رحمه الله وشراح الأحاديث للقواعد العهده الأصولية، وإعمالهم لها أثناء ممارسة عملية الاجتهاد 
إصدارات مؤسسة الشيخ محمد بن صالح العثيمين

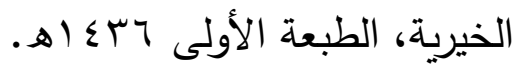
9 9. تيسير العلام شرح عمدة الأحكام، تأليف: عبدالله بن عبدالرحمن البسام (ت:بr § أه)، باشر

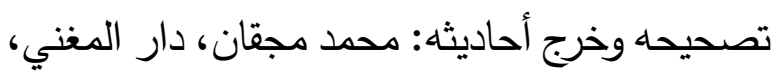

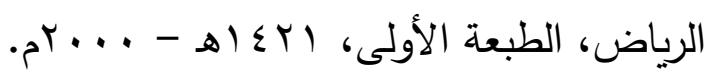

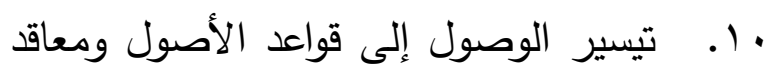
الفصول للإمام عبد المؤمن بن عبدالحق البغدادي الهي الحنبلي (ت:ته

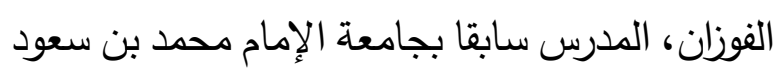
الإسلامية- فرع القصيم، دار ابن الجوزي، الطبعة

الثالثة، شوال 9 ؟ ا (هـ.

ا1. يسير مصطلح الحديث، بقلم: الدكتور

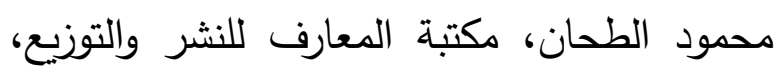

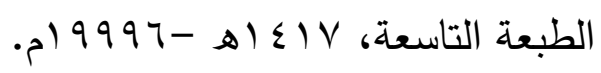
r I . ديوان جرير، دار صادر للطباعة والنشر،

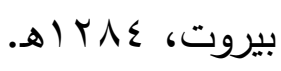
با. رياض الأفهام في شرح عمدة الأحكام،

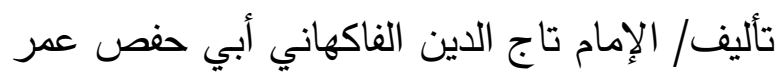

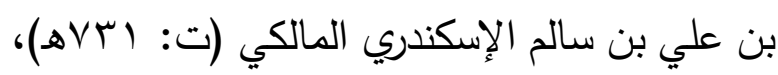

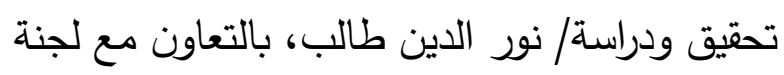

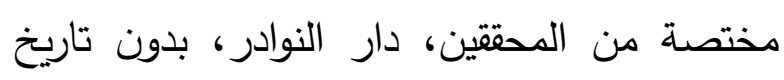
طبع. ع ا. شرح اللمع في أصول الفقه، للإمام أبي

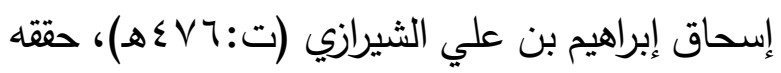

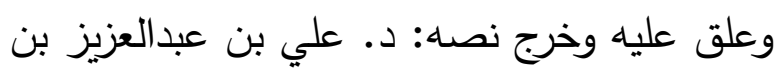

r. إحكام الفصول في أحكام الأصول، لأبي الوليد الباجي، حققه وقدم لله ووضع فهارسه:

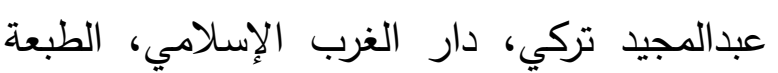

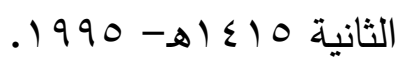

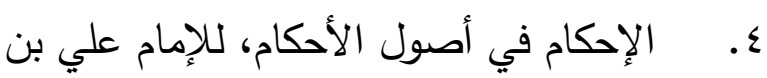

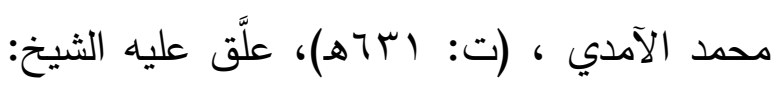

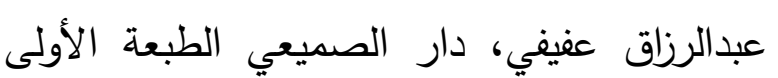
. 0. الإعلام بفوائد عمدة الأحكام، للإمام الحافظ أبي حفص عمر بن علي الأنصاري الثافعي المعروف بـ(ابن الملقِن)، تقديم فضيلة الثيخ صالح الفوزان، وفضيلة الثيخ بكر أبو زيد، حققه وضبط

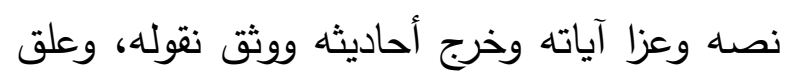

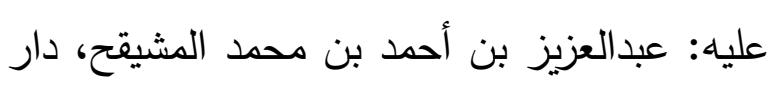

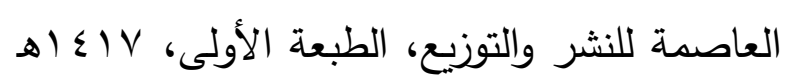
. ) $99 \mathrm{~V} \mathrm{-}$ 7. تحرير علوم الحديث، تأليف: عبدالله بن

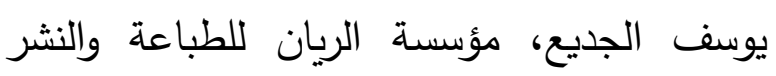

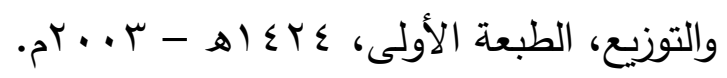

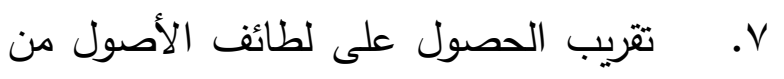
علم الأصول لفضيلة الثيخ العلامة محمد بن صالح

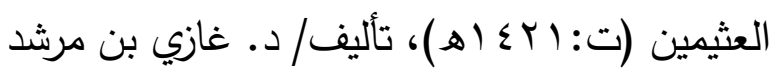

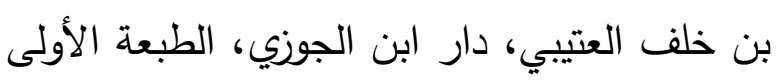
. ^. تبتيه الأفهام بشرح عمدة الأحكام، بقلم:

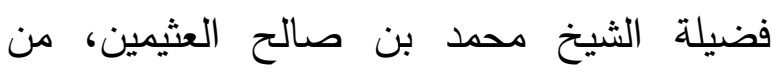


الطبعة الثانية، سب أهـ - r ا • rم.

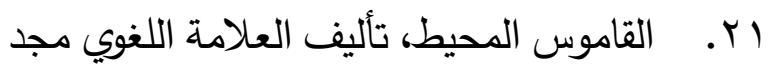
الدين محمد بن يعقوب الفيروز آبادي، (ت V ا Nهـ)، تحقيق مكتب التراث في مؤسسة الرسالة، بإشراف:

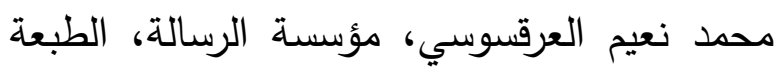
السادسة 9 (إ أهـ r. T. كشف اللثام شرح عمدة الأحكام، تأليف: شمس الدين محمد بن أحمد بن سالم السفاريني الحنبلي (ت: 11 1 (هـ)، اعتنى به تحقيقاً وضبطاً وتخريجاً: نور الدين طالب، دار النوادر، الطبعة

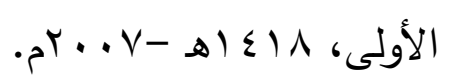

rץ. الكليات معجم في المصطلحات والفروق اللغوي، لأبي البقاء أيوب بن موسى الحسين الكفوي،

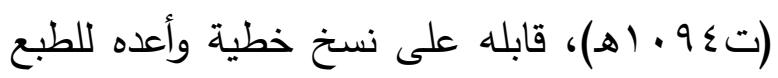
ووضع فهارسه الدكتور عدنان درويش ومحمد نهابه

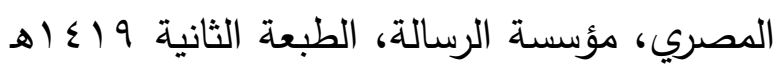
. $9191-$ צ. ـ. لسان العرب، لجمال الدين محمد بن مكرم

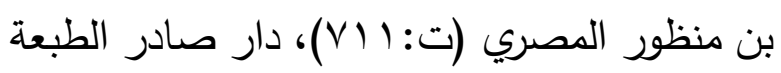

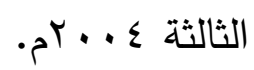
هץ. المحصول في علم أصول الفقه، فخر الدين

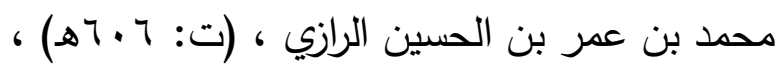

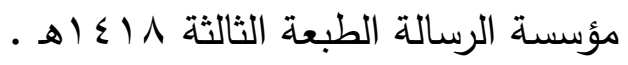

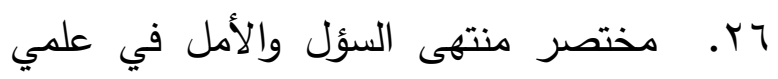
الأصول والجدل (المشتهرب: مختصر ابن الحاجب)، تأليف: جمال الدين أبي عمرو عثمان بن عمر بن
علي العميريني، الأستاذ المشارك بجامعة الإمام

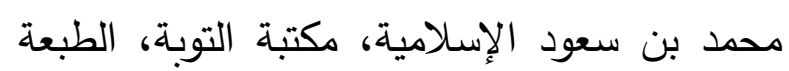

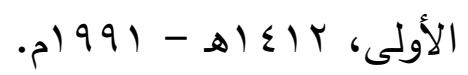

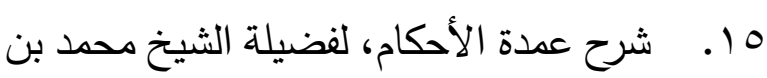

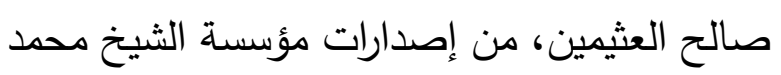

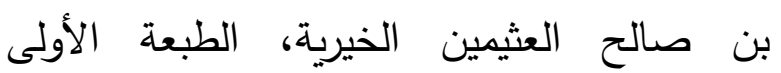
. ا ه $\leqslant r V$ 1 1 . صحيح البخاري، للإمام أبي عبدالله محمد اهد بن إسماعيل البخاري، (ت:بحه هـ)، دار السلام، الرياض، الطبعة الثانية 9 إـا هـ. له. IV الحجاج، (ت:آr هـ)، دار السلام، الرياض، لهاض

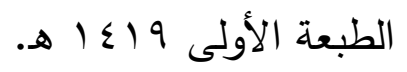

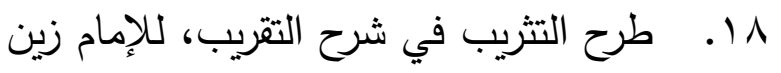

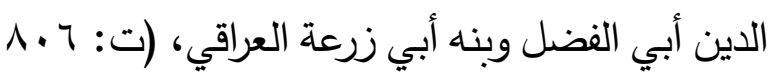

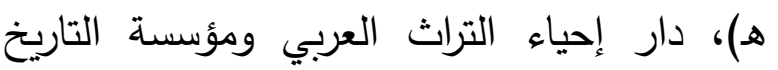

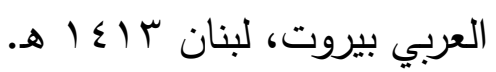
9 1. . العدَّة في إعراب العددة، تأليف: بدر الدين

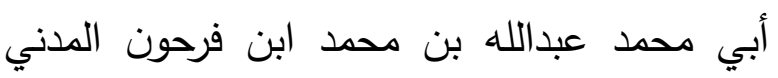
(ت:979هـ)، تحقيق: مكتب الهدي لتحقيق التراث،

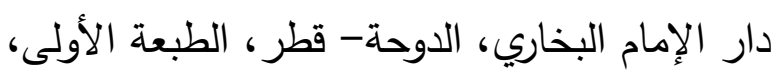
بدون تاريخ.

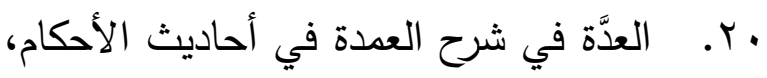

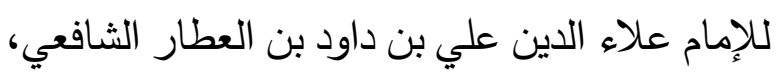

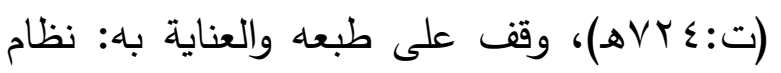

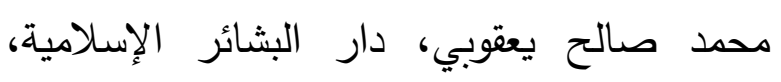


القلم - دمشق، الدار الثامية - بيروت، الطبعة

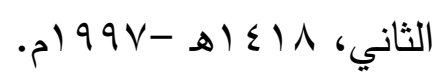

r r. مقاييس اللغة لأبي الحسين أحمد بن فارس بن زكريا (ت:90/هـ) دار الجيل بيروت تحقيق:

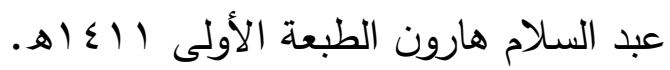

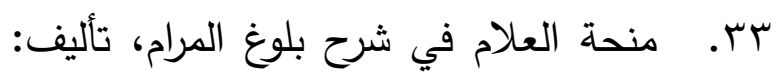

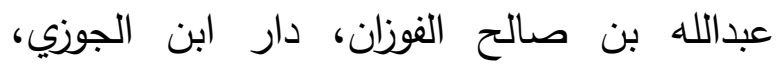

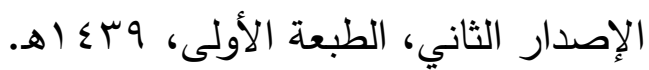
ع ז. منهاج الوصول إلى علم الأصول، تأليف:

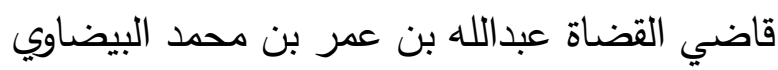

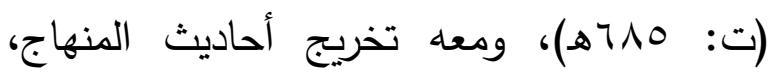
تأليف: الحافظ زيم الدين عبدالرحيم بن الحسين العراقي (ت:؟ • ^هـ)، تحقيق: سليم شعبانية، دار

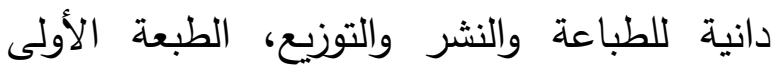
.019919
أبي بكر المعروف (بابن الحاجب) (ت:7 ז آه)، دراسة وتحقيق: الدكتور نذير حمادو أستاذ أصول الفقه ومقاصد الثريعة جامعة الأمير عبدالقادر للعلوم الإسلامية بالجزائر ، دار ابن حزم، الطبعة

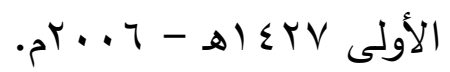
الاهد الا مختصر منتهى السؤل والأمل في علمي الأصول والجدل، تأليف الإمام العلامة جمال الدين أبي عمرو عثمان بن عمر بن أبي بكر المالكي

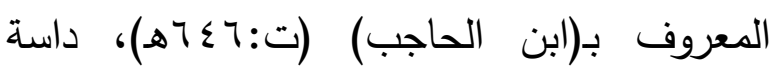
وتحقيق وتعليق/ د. نذير حمادو، أستاذ أصول الفقه

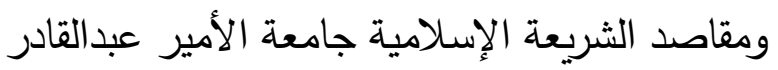
للعلوم الإسلامية (قسنطينه) الجزائر ، دار ابن حزم، الإميله

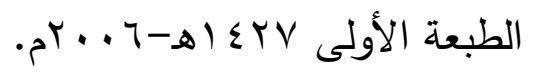
^r. . المستصفى من علم الأصول، لحجة الإسلام أبي حامد محمد بن محمد الغزالي (ت:0.0هـ)، تحقيق: محمد سليمان الأشقر، مؤسسة الرسالة

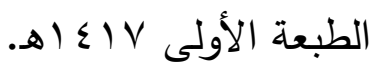
q. المصفَّى في أصول الفقه، تأليف/ أحمد بن الاول محمد بن علي الوزير (ت:YVY أه)، دار الفكر

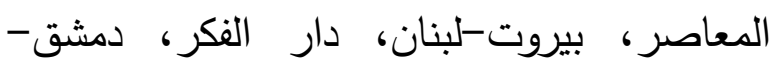

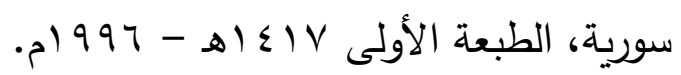
•r. معالم أصول الفقه عند أهل السنة والجماعة الهاعل ، لمحمد بن حسين الجيزاني ، دار ابن الجوزي

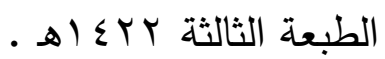
اس. مفردات ألفاظ القرآن، تأليف: العلامة الراغب الأصفهاني، تحقيق: صفوان عدنان داوودي، دار 


\title{
Fundamentalistic Applications on the Ahadeeth of Rulings (Some purification Ahadeeth from Umdat Al-Ahkam "the Mayor of Rulings" as an Exemplar)
}

\author{
Dr. Mashhour Hatim Hamid Alharthy \\ Associate professor of fundamentalistic jurisprudence (Usul Al-Fiqh) \\ King Abdulaziz University in Jeddah \\ College of Arts and Humanities \\ Department of Shari'a (Islamic Law)
}

\begin{abstract}
this research titled, "Fundamentalistic Applications on the Ahadeeth of Rulings (Some purification Ahadeeth from Umdat Al-Ahkam "the Mayor of Rulings" as an Exemplar)" in which I strived to illustrate the importance of the science of Islamic Fundamentalistic Jurisprudence (Usul Al-Fiqh) and its impact on understanding the Islamic texts, especially on correct deduction. It is obvious that this is one of the most important objectives of the science of Islamic Fundamentalistic Jurisprudence (Usul Al-Fiqh). If it lacks it, it would be a science with little benefit and poor efficacy.

I divided this research into three sections and a conclusion. The first section covers the definition of the fundamentalistic application, linguistically and religiously. The second section covers defining the Ahadeeth of rulings, linguistically and religiously. The third section covers fundamentalistic applications on some of the purification Ahadeeth. I chose six Ahadeeth from the bookUmdat Al-Ahkam "the Mayor of Rulings" from the purification chapters by Imam Al-Maqdisi, May Allah have mercy on his soul. I applied the fundamentalistic and jurisprudential principles to them.

I ask Allah the Almighty to make this research for him, beneficial for his worshippers, and peace and blessings are being due to the prophet.
\end{abstract}

